\title{
Bioactive Edible Films and Coatings Based in Gums and Starch: Phenolic Enrichment and Foods Application
}

\author{
Sónia Pedreiro ${ }^{1,2}$, Artur Figueirinha ${ }^{1,2}$ (D) Ana Sanches Silva $1,3,4$ (D) and Fernando Ramos $1,2, *$ (D) \\ 1 Faculty of Pharmacy, University of Coimbra, Azinhaga de Santa Comba, 3000-548 Coimbra, Portugal; \\ sorapedreiro@gmail.com (S.P.); amfigueirinha@ff.uc.pt (A.F.); ana.silva@iniav.pt (A.S.S.) \\ 2 REQUIMTE/LAQV, R. D. Manuel II, Apartado, 55142 Oporto, Portugal \\ 3 National Institute for Agricultural and Veterinary Research (INIAV), I.P., Rua dos Lagidos, \\ Lugar da Madalena, Vairão, 4485-655 Vila do Conde, Portugal \\ 4 Center for Study in Animal Science (CECA), ICETA, University of Oporto, Apartado, 55142 Oporto, Portugal \\ * Correspondence: author: framos@ff.uc.pt
}

check for updates

Citation: Pedreiro, S.; Figueirinha, A.; Silva, A.S.; Ramos, F. Bioactive Edible Films and Coatings Based in Gums and Starch: Phenolic Enrichment and Foods Application Coatings 2021, 11, 1393. https:// doi.org/10.3390/coatings11111393

Academic Editor: Monica Trif

Received: 3 October 2021

Accepted: 11 November 2021

Published: 15 November 2021

Publisher's Note: MDPI stays neutral with regard to jurisdictional claims in published maps and institutional affiliations.

Copyright: (c) 2021 by the authors. Licensee MDPI, Basel, Switzerland. This article is an open access article distributed under the terms and conditions of the Creative Commons Attribution (CC BY) license (https:// creativecommons.org/licenses/by/ $4.0 /)$

\begin{abstract}
Edible films and coatings allow preserving fresh and processed food, maintaining quality, preventing microbial contamination and/or oxidation reactions and increasing the shelf life of food products. The structural matrix of edible films and coatings is mainly constituted by proteins, lipids or polysaccharides. However, it is possible to increase the bioactive potential of these polymeric matrices by adding phenolic compounds obtained from plant extracts. Phenolic compounds are known to possess several biological properties such as antioxidant and antimicrobial properties. Incorporating phenolic compounds enriched plant extracts in edible films and coatings contribute to preventing food spoilage/deterioration and the extension of shelf life. This review is focused on edible films and coatings based on gums and starch. Special attention is given to bioactive edible films and coatings incorporating plant extracts enriched in phenolic compounds.
\end{abstract}

Keywords: edible coatings and films; phenolic compounds; starches; gums; antioxidant activity

\section{Introduction}

According to Adeyeye and co-workers [1], "Packaging is all products that are of any nature and used as the containment, handling, protection, presentation, and delivery of goods from the raw materials state to the processed goods and from the producers to the consumers." Therefore, food packaging is responsible for the containment and protection of food from spoilage, contributing to its validity, and should protect against microbial, chemical and environmental contaminants in assuring food quality and safety and increasing the shelf life of food products [2,3]. However, conventional plastics used for food packaging have some production and environmental issues due to the fact they are based on petroleum, are non-renewable or non-degradable, emit greenhouse gases and present a severe waste disposal concern $[1,4,5]$. Therefore, it is important to develop new packaging materials that are more sustainable and "green" with the same functions as conventional packaging $[1,2,6,7]$.

In an attempt to solve this problem, biopolymers/bioplastics emerged. Biopolymers are organic polymers and according with its origin are classified, mainly, into three types: biomass-derived polymers (e.g., proteins and polysaccharides including chitosan, starch and cellulose); synthetic polymers derived from oil or biomass monomers such as polylactic acid (PLA), polycaprolactones (PCL) and polyvinyl alcohol (PVA); polymers produced by natural microorganisms or genetically modified (e.g., polyhydroxyalcanoates and bacterial cellulose) $[1,6,8-10]$. In general, bioplastics present some advantages relative to common plastics: namely, they use less energy and are biodegradable, safe and emit less greenhouse gases; provide longer shelf life and are suitable for the production of compost; the chemical structure is more diversified, making possible the customization of the properties of the final package according to the type of food; and possibility of nanoparticles incorporation and adding or improving important properties such as thermic stability, gas impermeability/barrier including 
to oxygen, antimicrobial properties and strength $[4,9]$. Regardless of these advantages, bioplastics have some issues concerning its mechanical and barriers properties, which require the addition of additives or other synthetic polymers (e.g., via hydroxypropylation) improving the referred properties [1,7]. Therefore, biopolymers may not be $100 \%$ made of renewable sources as some are blends of natural polymers with synthetic polymers or incorporate additives that improve the functional properties of the final package [1].

Biopolymers are used to prepare edible films and coatings, materials with thickness below $0.3 \mathrm{~mm}$ that are produced through a blend of biopolymers with different additives dispersed in an aqueous phase, and are safe to eat [5,11,12]. Edible films and coatings are easily manufactured, economically viable [13] and provide mechanical protection and improvement of food quality through moisture regulation and internal equilibrium between gases and solutes $[5,12,13]$. In addition to that, these materials can protect against UV radiation, fungi and bacterial contamination [5]. Edible films and coatings have the capacity to carry bioactive compounds, such as phenolic compounds, vitamins, nutraceuticals and probiotics, which improve food quality and, at the same time, provide additional health properties to the consumer after food consumption [5,14]. All these characteristics contribute to shelf-life increase [5,12] and a reduction in the use of additives [15]. In general, edible films and coatings are classified into the following: oil/water emulsions and colloidal dispersions [5]. They can be applied by dipping, spreading, spraying and wrapping (Figure 1) $[5,12,13]$. They can also be classified according to the type of application: edible coatings applied by dipping, spreading or spraying and edible films produced by compression molding, solvent casting or extrusion and that are used to wrap food [5,12].

(a)

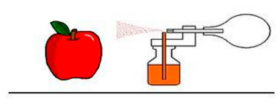

(c)

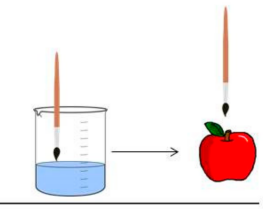

(b)

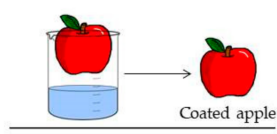

(d)

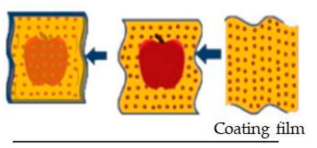

Figure 1. Schematic representation of coating techniques: (a) spraying; (b) dipping; (c) spreading and (d) wrapping (adapted from [16]).

In the food industry, food is submitted to several treatments (e.g., heat treatment, $\mathrm{pH}$ reduction, salting and drying) in order to prevent fungal and bacterial growth contamination, and synthetic antioxidants, namely butylated hydroxyanisole (BHA) and butylated hydroxytoluene (BHT), are frequently added to prevent lipid oxidation [14,17]. However, nowadays, consumers tend to prefer food products that are minimally processed and that are healthier $[14,18,19]$. In this line, the scientific community evaluated the possibility of incorporating bioactive compounds (antioxidants, antimicrobials, flavours and probiotics) in food packaging, mainly in edible films and coatings to prevent microbiological contaminations and/or oxidative processes [14,18]. Natural antioxidants such as phenols, carotenoids and ascorbic acid are extracted from plants, vegetables, fruits, oil seeds and cereal crops $[18,20,21]$. Many phenolic compounds and essential oils from plants have antimicrobial activity [20] such as lemongrass, oregano, cinnamon, garlic [18] and thymus [21].

This review reports the most recent studies in this area and specifically gathers information about phenolic compounds incorporation in starch and gum edible films. The compilation of information is carried out in a systematic manner and is an asset for those who want to start studies in the scope of edible packaging based on gums and starches. 


\section{Gums Used in Food Packaging}

Gums are complex polysaccharides of high molecular weight composed of glucose, fructose, mannose and other sugars [22], and they have the ability to form gels or mucilages [23]. They are also called hydrocolloids because of their solubility in water [23,24]. Gums are chemically inert, biocompatible, non-toxic, odourless and widely available in the nature [24]. Due to their chemical structure and properties, gums are used in the industry, namely in cosmetic [25], pharmaceutical [26] and food industry [24-27] as gel, thickener, moisturizer, emulsifier, stabilizer [23], coating agents and packaging films [27]. Natural gums are derived from plants, bacteria and animals [23]. In the vegetable kingdom, gums provide protection against microbial or mechanical injury $[24,25]$ and can be found in plant seed endosperm (e.g., guar gum) [24,25]; plant exudates [24,25], shrubs or trees; and algae extracts (agar) [23]. The gums xanthan, pullulan, curdlan, gellan and cellulose are microbial gums, and according to their physicochemical properties, they are used to form gels (e.g., curdlan and gellan), thickeners agents (xanthan and pullulan) and film solutions (e.g., cellulose, pullulan and gellan) [22]. Examples of tree gums extruded are Arabic gum, tragacanth gum, ghatti gum, Persian gum, karaya gum and cashew gum [27]. Locust bean, guar gum (Figure 2), tara gum, basil gum, flaxseed gum, psyllium gum and Barhang gum are from seeds [27]. Konjac mannan is a tuber gum [27].

Xanthan gum (Figure 2), a Generally Recognized as Safe compound (GRAS) [22], is an exopolysaccharide produced by the bacteria Xanthomonas campestris at unfavorable conditions by fermentation [28-31]. Xanthan gum is an anionic polymer constituted by $\beta-(1 / 4)-D-$ glucopyranose glucan (similar to cellulose) as a base framework and by the residues -(3/1)$\alpha$-linked D-mannopyranose-(2/1)- $\beta$-D-glucuronic acid-(4/1)- $\beta$-D-mannopyranose [23,30]. At low concentrations, xanthan gum presents high viscosity, and it is soluble in water, stable at a wide range of $\mathrm{pH}$ and temperature $[10,23]$ and has resistance to enzymatic degradation. In 1969, xanthan gum was approved by FDA as a food additive [22], and later in 1980, it was recognized by the European Union under designation E415 [30] to be used as a stabilizing and thickening agent $[32,33]$. Moreover, in addition to its uses in the food industry as a stabilizer and thickener, xanthan gum is also used as gel, emulsifier and as an adhesive to prevent the formation of ice crystal [30]. In addition, the safety of xanthan gum as a food additive was re-assessed by EFSA in 2017, and this additive was considered safe for human consumption [31].

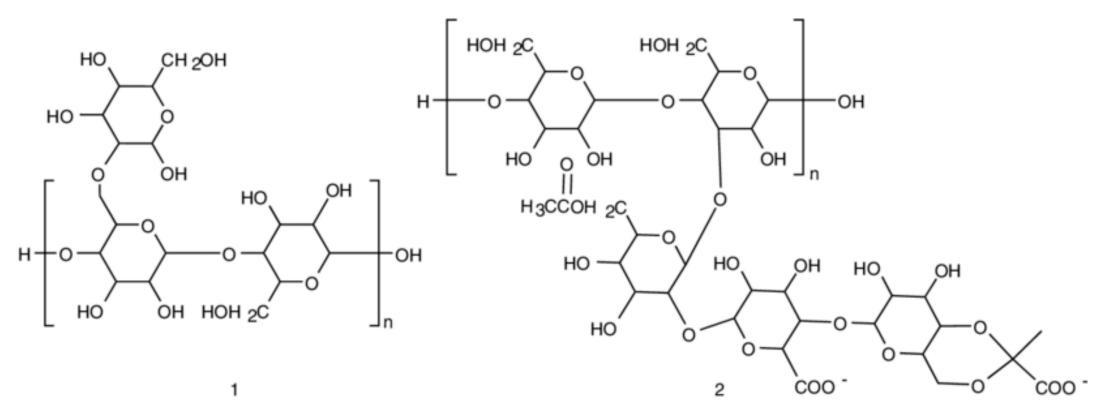

Figure 2. Struturee of guar gum (1) and xanthan gum (2) (retired from [33]).

Table 1 summarizes some of the gums used as food coatings or films and their properties as edible food packaging. In a general manner, most of the edible coatings of gums have antimicrobial properties, inhibiting its growth, preventing weight and moisture loss, providing firmness and preserving the organoleptic properties of the food, which, in this manner, contributes to quality maintenance and shelf-life extension. According with the data compiled in Table 1, xanthan, Arabic and guar gums are the most used gums in producing edible packaging. Moreover, dipping and immersion are the most commonly used food application methods. 
Table 1. Gums coatings and films with or without incorporation of bioactive compounds and their properties as food preservatives.

\begin{tabular}{|c|c|c|c|c|c|c|}
\hline Polysaccharide & Food Application & $\begin{array}{l}\text { Bioactive Compounds } \\
\text { Incorporated }\end{array}$ & Type of Packaging & $\begin{array}{l}\text { Application Coating } \\
\text { Method }\end{array}$ & Results & References \\
\hline \multirow{5}{*}{ Xanthan } & Melon & $\beta$-carotene nanoparticles & Coating & Immersion & $\begin{array}{l}\text { Improvement of coatings properties and } \\
\text { increase in shelf time to } 21 \text { days at } 4{ }^{\circ} \mathrm{C}\end{array}$ & {$[34,35]$} \\
\hline & Refrigerated fish & Chitosan & Film & - & $\begin{array}{l}\text { Inhibition of the growth of Staphylococcus } \\
\text { coagulase-positive, Salmonella spp. and coliforms } \\
\text { at } 45{ }^{\circ} \mathrm{C}\end{array}$ & [36] \\
\hline & Acerola & - & Coating & - & $\begin{array}{c}\text { Quality preservation } \\
\text { Reduction of weight loss and the respiration } \\
\text { process } \\
\text { Increase in shelf life (prolongation of } 6 \text { days at } \\
30^{\circ} \mathrm{C} \text { without deterioration signs }\end{array}$ & [10] \\
\hline & Pear & - & Coating & - & $\begin{array}{l}\text { Retained the weight during } 9 \text { days of storage } \\
\text { Prevention of oxidation }\end{array}$ & [37] \\
\hline & Baby carrots & $\alpha$-tocopherol & Coating & Dipping & $\begin{array}{l}\text { Edible coatings improve the surface colour } \\
\text { without organoleptic properties alterations }\end{array}$ & [38] \\
\hline \multirow[t]{8}{*}{ Galactomannan } & Ricotta cheese & Nisin & Coating & Dipping & $\begin{array}{l}\text { Delay of microbial growth during } 28 \text { days } \\
\text { Weight loss and moisture content decreasing }\end{array}$ & {$[39,40]$} \\
\hline & Fruits & Nisin & - & - & $\begin{array}{l}\text { Decrease in gas transfer rates } \\
\text { Strong antibacterial activity against }\end{array}$ & [40-42] \\
\hline & - & $\mathrm{Ag} / \mathrm{Cu}$ nanoparticles & Film & Spreading & $\begin{array}{c}\text { Gram-positive Listeria monocytogenes bacteria } \\
\text { and Gram-negative Salmonella enterica sv } \\
\text { typhimurium } \\
\text { Excellent UV, light and oxygen barrier } \\
\text { capability } \\
\text { Firmness enhancement }\end{array}$ & - \\
\hline & Roma tomato & - & Coating & Immersion & $\begin{array}{l}\text { Reduce the weight loss } \\
\text { Retarded loss of total acidity } \\
\text { Respiration rate decrease }\end{array}$ & [42] \\
\hline & Blackberries & - & - & - & $\begin{array}{l}\text { Shelf-life extension for } 13 \text { days } \\
\text { Shelf-life extension }\end{array}$ & [43] \\
\hline & lemon & Spice extracts & Coating & Dipping & $\begin{array}{l}\text { Maintenance of quality during cold storage } \\
\text { Inhibition of bacterial growth } \\
\text { Maintenance of fruit quality }\end{array}$ & [44] \\
\hline & Litchi fruits & - & Coating & - & $\begin{array}{c}\text { Shelf-life extension up to } 10 \text { days under low } \\
\text { temperature storage }\end{array}$ & [45] \\
\hline & Red chilli pepper & - & Coating & Dipping & $\begin{array}{c}\text { Maintenance of fruit quality without } \\
\text { deterioration during } 20 \text { days at storage } \\
\text { temperature of } 6{ }^{\circ} \mathrm{C}\end{array}$ & [46] \\
\hline
\end{tabular}


Table 1. Cont.

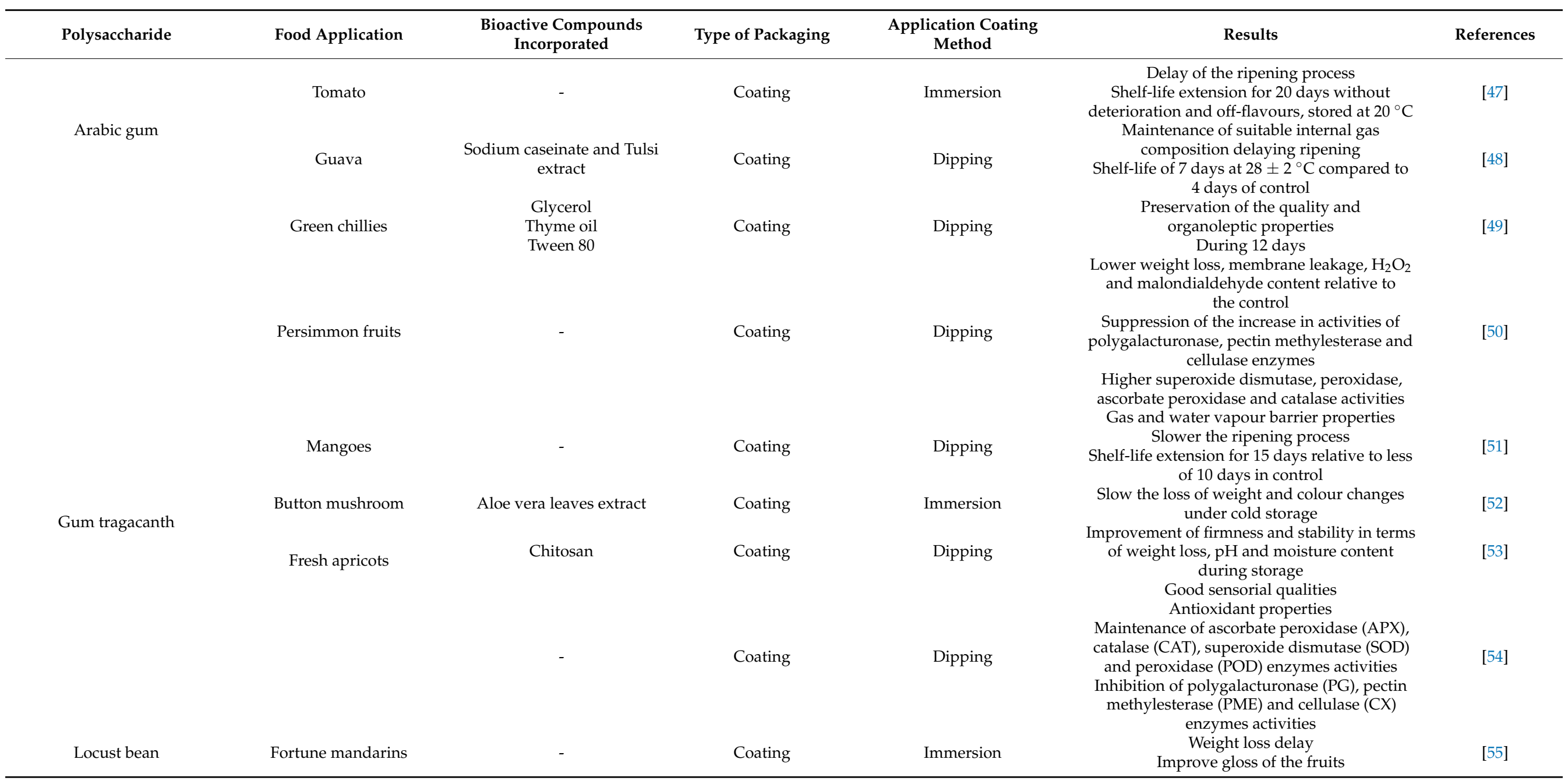


Table 1. Cont.

\begin{tabular}{|c|c|c|c|c|c|c|}
\hline Polysaccharide & Food Application & $\begin{array}{l}\text { Bioactive Compounds } \\
\text { Incorporated }\end{array}$ & Type of Packaging & $\begin{array}{l}\text { Application Coating } \\
\text { Method }\end{array}$ & Results & References \\
\hline \multirow[t]{3}{*}{ Konjac glucomanann } & Fresh-cut cucumber & Saffron petal extract & Film & - & $\begin{array}{l}\text { Reduction in the water vapour permeability } \\
\text { Antimicrobial properties against Escherichia coli } \\
\text { (E. coli), Shigella sonnei, Salmonella Typhi, } \\
\text { Staphylococcus aureus (S. aureus) and } \\
\text { Bacillus cereus } \\
\text { Preservation of fruits and vegetables quality } \\
\text { Shelf-life extension }\end{array}$ & [56] \\
\hline & Guava & - & Coating & Immersion & $\begin{array}{l}\text { Maintenance of firmness and colour } \\
\text { Reduce weight loss } \\
\text { Maintenance of weight loss, hardness }\end{array}$ & [57] \\
\hline & Cantaloupe & Potassium sorbate & Coating & - & $\begin{array}{l}\text { and firmness } \\
\text { Inhibition of microbial growth } \\
\text { Preservation of sliced cantaloupe up to } 5 \text { days }\end{array}$ & [58] \\
\hline Gellan gum & Mango & - & Coating & Dipping & $\begin{array}{l}\text { Improvement of sensorial characteristics } \\
\text { namely appearance and firmness } \\
\text { Stabilization of colour and volatiles } \\
\text { composition during storage }\end{array}$ & [59] \\
\hline \multirow[t]{2}{*}{ Almond gum/Persian gum } & Tomato & - & Coating & Immersion & $\begin{array}{l}\text { Delay changes in colour, weight loss, firmness, } \\
\text { acidity, ascorbic acid content, soluble solids } \\
\text { concentration and decay percentage during a } \\
\text { storage period of } 20 \text { days. }\end{array}$ & [60] \\
\hline & Cherries & Gum Arabic & Coating & Immersion & $\begin{array}{c}\text { Delay the ripening process and increase the } \\
\text { shelf life of cherries without spoilage or } \\
\text { off-flavour }\end{array}$ & {$[61,62]$} \\
\hline
\end{tabular}




\section{Starches Used in Food Packaging}

Starch is produced by plants, some strains of fungi and algae and is used for energy storage [63]. It comprises amylose and amylopectin polymers (Figure 3) $[7,64,65]$ made up of $\alpha$-D-glucose monomers [7,64]. Amylose is mainly a linear polymer where $\alpha$-D-glucose monomers are linked by $\alpha-1,4$-glycosidic bonds with some ramifications connected by $\alpha-1,6$-glycosidic bonds while amylopectin is a branched polymer linked by $\alpha-1,4$ and $\alpha-1,6$ glycosidic bonds $[7,64]$. In general, starch has more amylopectin abundance than amylose although this ratio depends on the starch origin, resulting in a range of granules crystallinities [64,65]. Starch can be found in potato, cassava, wheat, rice, corn, maize, bean and in other sources [2,64].

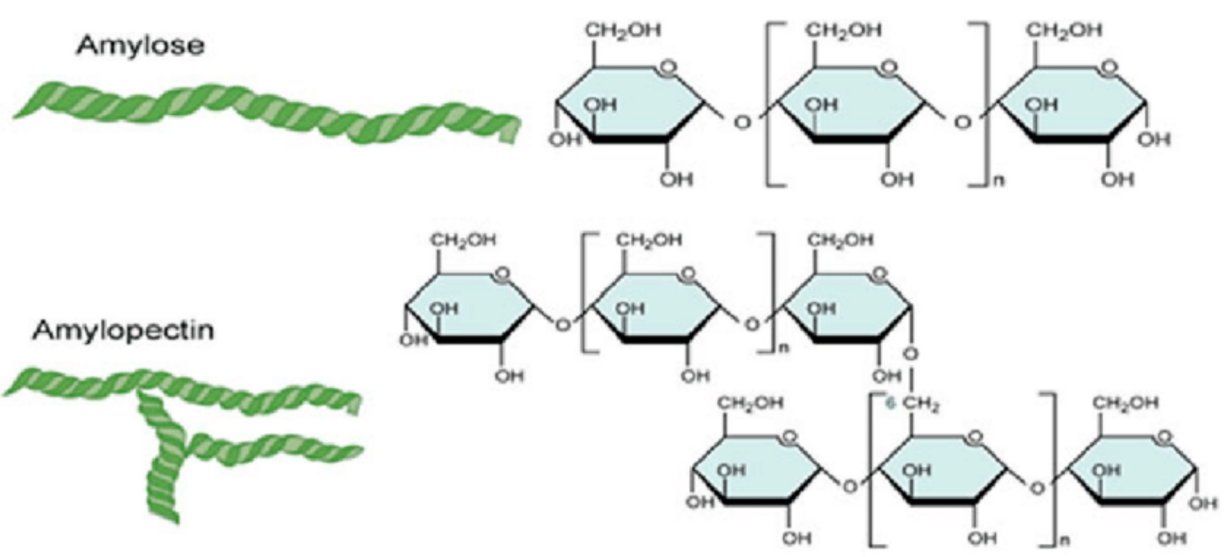

Figure 3. Structure of amylose and amylopectin that constitute starch molecule (retired from [65]).

In the food industry, starch is used in food packaging as coatings or films produced mainly by extrusion and casting [2]. In the manufacture of starch edible coatings, amylose is preferred over amylopectin [66]. Starch based films are low cost, abundant, tasteless, colourless and odourless with very good oxygen barrier properties (due to its compact structure and low solubility) contributing to the improvement of food preservation and, consequently, its shelf-life extension [65-67]. In addition, starch is biodegradable and edible [67]. However, starch presents some disadvantages due to its hydrophilic nature caused by hydroxyl groups and formation of hydrogen bonds among starch molecules [66]. The hydrophilic nature of starch-based films is responsible for moisture absorption, resulting in swelling of the starch matrix, disruption of $\mathrm{H}$ bonds and increase in free volume within the starch-based film matrix. These events cause the weakening of moisture and gases barriers and low water vapour barrier capacity $[7,68]$. In addition, starch films have poor mechanical properties, resulting in the use of additives, including plasticizers (e.g., glycerol and sorbitol) [68] and hydrophobic substances [67] in order to improve these properties [64]. Although starch is relatively cheap, the incorporation of others substances to improve the film matrix makes starch films more expensive [64].

In food packaging, corn-starch is used as thermoplastic starch and is commercially available under brand names such as EcoframTM (National starch), solanylTM (Rodenburg biopolymers), BiocoolTM (Novamont), BioplastTM (Biotec) and PlanticTM from Plantic Tecnhologies [69]. Table 2 summarizes the uses of starch-based edible films and its benefits in food packaging. Among the described starch-based coatings and films compiled in Table 2, cassava starch is the most commonly used. Starch-based coatings and films are mainly applied in highly perishable foods such as fruits and vegetables. 
Table 2. Starch based coatings and films with or without incorporation of bioactive compounds and their properties as food preservatives.

\begin{tabular}{|c|c|c|c|c|c|c|}
\hline Starch Source & Food Application & Bioactive Compounds & $\begin{array}{c}\text { Type of } \\
\text { Packaging }\end{array}$ & $\begin{array}{l}\text { Application Coating } \\
\text { Method }\end{array}$ & Results & References \\
\hline $\begin{array}{l}\text { Tropical fruits: banana } \\
\text { "Pear", soursop, } \\
\text { stenospermocarpic } \\
\text { mango }\end{array}$ & $\begin{array}{l}\text { Stenospermocarpic } \\
\text { mangoes }\end{array}$ & - & Coating & Immersion & $\begin{array}{l}\text { Mango starch showed better results than the } \\
\text { other starches coatings tested: less weight loss, } \\
\text { greater firmness, high content of total soluble } \\
\text { solid and shelf-life extension up to } 15 \text { days } \\
\left(10 \text { days at } 10^{\circ} \mathrm{C} \text { and } 5 \text { days at } 22^{\circ} \mathrm{C}\right)\end{array}$ & {$[70]$} \\
\hline Corn & Banana & $\begin{array}{l}\text { Gum Arabic } \\
\text { Glycerol } \\
\text { Sorbitol }\end{array}$ & Film & Dipping & $\begin{array}{c}\text { At a temperature of } 26^{\circ} \mathrm{C} \text {, the coated fruits lose } \\
\text { less weight than control (uncoated fruits), } \\
\text { retaining firmness and delaying the } \\
\text { ripening process }\end{array}$ & [71] \\
\hline Cassava & Mango & Chitosan & Coating & Immersion & $\begin{array}{l}\text { At } 25^{\circ} \mathrm{C} \text {, the coating showed good sensorial } \\
\text { qualities and decreased respiration rate without } \\
\text { prejudicing the ripening process } \\
\text { Shelf-life extension up to } 3 \text { days }\end{array}$ & {$[72]$} \\
\hline Rice and cassava & Pummelo & Pummelo juice & Film & Immersion & $\begin{array}{l}\text { Lower weight loss } \\
\text { Physical appearance stabilization }\end{array}$ & [73] \\
\hline Potato & “Orri” mandarins & Glycerol & Coating & Immersion & Weight loss reduction & [74] \\
\hline Tapioca & Cauliflower & Gelatin & Coating & Dipping & $\begin{array}{l}\text { Weight loss reduction } \\
\text { Total soluble solids increase }\end{array}$ & [75] \\
\hline Cassava & Blackberries & $\begin{array}{l}\text { Chitosan } \\
\text { Glycerol }\end{array}$ & Coating & Immersion & $\begin{array}{l}\text { Good sensorial properties (colour maintenance) } \\
\text { Weight loss reduction and firmness increase } \\
\text { during } 10 \text { days of storage }\end{array}$ & [76] \\
\hline Banana "Pear" & Mango & Pectin & Coating & - & $\begin{array}{c}\text { High firmness } \\
\text { High total soluble solids } \\
\text { Post harvested period extended to } 21 \text { days } \\
\text { Retention of colour mango fruits }\end{array}$ & [77] \\
\hline Wheat & Plums & - & Coating & Immersion & $\begin{array}{l}\text { No colour changes } \\
\text { Improvement of water vapour and oxygen } \\
\text { permeability }\end{array}$ & [78] \\
\hline Chickpea & Papaya & $\begin{array}{l}\text { Glycerol } \\
\text { Stearic acid }\end{array}$ & Film & Dipping & $\begin{array}{l}\text { Reduced weight loss, better firmness and colour } \\
\text { retention at } 10^{\circ} \mathrm{C} \text { during } 10 \text { days of storage }\end{array}$ & [79] \\
\hline
\end{tabular}


Table 2. Cont.

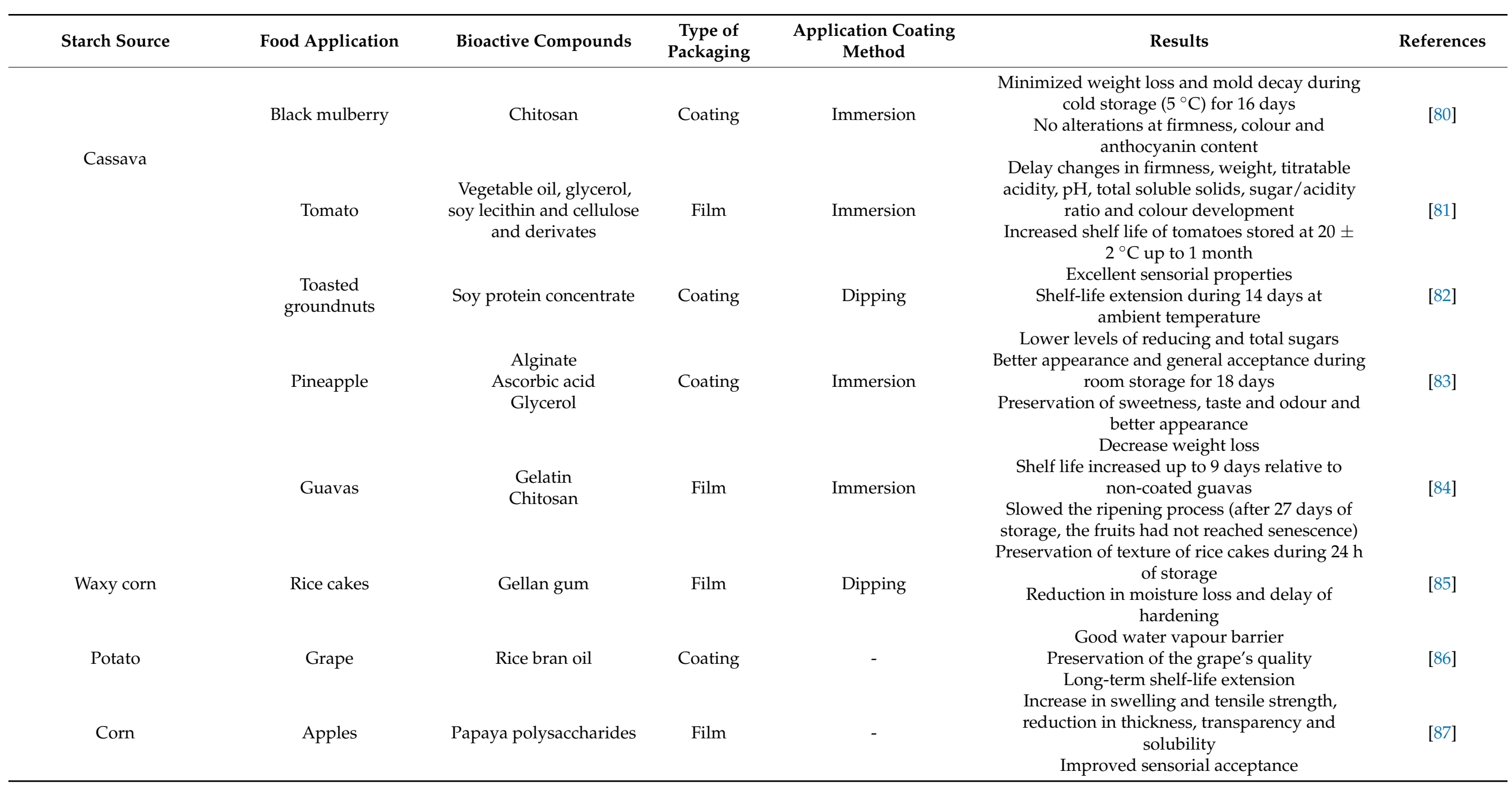




\section{Methods of Incorporation Phenolic Compounds in Gums and Starch-Based Coatings and Films}

The incorporation of phenolic compounds must consider final packaging characteristics, the bioactive substances used and their application in foods. To produce active films, the incorporation of bioactive compounds can be made by mixing them directly with films production or by encapsulation resulting in nanoparticles formation [88]. The usual methods for starch films production are by casting, pressing and extrusion [88]. The solvent casting method is the most used for the incorporation of phenolic compounds in polysaccharide films or coatings [89]. With respect to the formation of film, the polymeric solution is spread on the intended surface and posteriorly air dried in a ventilated oven. After solvent evaporation, the film is removed from the surface maintaining the surface form. However, the removal of film surface can cause it to wrinkle and tear. The physicochemical properties of films depend on the composition of casting solution, wet casting thickness, temperature and relative humidity conditions [89]. The extrusion method is based on the thermoplastic properties of biopolymers. The biopolymer solution contains a plasticizer that is heated above its glass transition temperature under reduced water conditions. Posteriorly, the films are submitted to compression, casting and extrusion, resulting in the formation of more elastic films [89]. The applications of coatings, thickness and their ability to adhere to food surface are important characteristics for food quality preservation. Therefore, coatings can be applied by spraying, dipping and spreading [89].

Table 3 summarizes some of the used formulations for incorporating polyphenols in active starch/gums films. Active starch and gum-based films and coatings were prepared mainly by casting method. Glycerol was the most used plasticizer in the preparation of active coating and films [90-94]. In general, the percentage of bioactive compound or extract in starch and gum-based coatings is low, ranging between 0.03 and $1.20 \%$, and all the extracts and isolated bioactive compounds tested acted at the level of lipidic oxidation and microbiological contamination, preventing food spoilage and increasing its shelf-life. 
Table 3. Formulations and main effects of phenolic compounds incorporated in starch and gums edible films or coatings.

\begin{tabular}{|c|c|c|c|c|c|c|c|}
\hline Active Compound. & $\begin{array}{c}\% \text { of Bioactive } \\
\text { Compound/Extract } \\
\text { in the Formulation }\end{array}$ & Material Base & Methodology & $\begin{array}{c}\text { Food Application to } \\
\text { Evaluate } \\
\text { Effectiveness }\end{array}$ & $\begin{array}{c}\text { Means/Tests/Assays for } \\
\text { the Evaluation of Films } \\
\text { Effectiveness }\end{array}$ & $\begin{array}{c}\text { Main Effects/Conclusions } \\
\text { of the Study }\end{array}$ & Reference \\
\hline Green tea & $5 \%$ & Cassava starch & Casting & Butter & $\begin{array}{c}\text { Film characterization } \\
\text { (thickness, mechanical } \\
\text { properties and water } \\
\text { vapour permeability); } \\
\text { peroxide index }\end{array}$ & $\begin{array}{l}\text { Improved functional } \\
\text { properties mechanical, water } \\
\text { vapour barrier and } \\
\text { antioxidant properties of the } \\
\text { resulting films. The results } \\
\text { provide oxidative protection } \\
\text { in packaged butter, by } \\
\text { decreasing peroxide index, } \\
\text { when using these film } \\
\text { additives at low } \\
\text { concentrations }\end{array}$ & [90] \\
\hline Tea polyphenols & $\begin{array}{c}0.06 \%, 0.03 \% \text { and } \\
0.6 \%\end{array}$ & $\begin{array}{l}\text { Hydroxypropyl } \\
\text { starch }\end{array}$ & Casting & $\mathrm{N} / \mathrm{A}$ & $\begin{array}{c}\text { Antioxidant tests } \\
\text { performed by using } \\
\text { DPPH free radical assay } \\
\text { scavenging; } \\
\text { Antimicrobial activity } \\
\text { against Gram-positive } \\
\text { bacteria } \text { S. aureus and } \\
\text { Gram-negative bacteria } \\
\text { E. coli was evaluated by } \\
\text { shake } \\
\text { flask culture method }\end{array}$ & $\begin{array}{l}\text { Slight impact on the surface } \\
\text { and barrier properties of the } \\
\text { films due to a good } \\
\text { dispersity of tea polyphenols } \\
\text { in the starch matrix through } \\
\text { hydrogen bonding improved } \\
\text { antioxidant activity and } \\
\text { antimicrobial activity, while } \\
\text { inducing a decrease in } \\
\text { mechanical properties }\end{array}$ & [91] \\
\hline $\begin{array}{l}\text { Pink pepper phenolic } \\
\text { compounds }\end{array}$ & $4 \%, 6 \%$ and $8 \%, v / w$ & $\begin{array}{l}\text { Rice starch } / \text { fish } \\
\text { protein }\end{array}$ & Casting & Fresh-cut apples & $\begin{array}{c}\text { Evaluation of } \\
\text { antioxidant activity by } \\
\text { DPPH assay and } \\
\text { inhibition of peroxidase }\end{array}$ & $\begin{array}{l}\text { Rice starch/fish protein } \\
\text { films with } 6 \%(v / w) \text { pink } \\
\text { pepper phenolic compounds } \\
\text { achieved better conservation } \\
\text { during } 12 \text { days, especially in } \\
\text { terms of inhibition of } \\
\text { enzymatic browning. }\end{array}$ & [94] \\
\hline
\end{tabular}


Table 3. Cont.

\begin{tabular}{|c|c|c|c|c|c|c|c|}
\hline Active Compound. & $\begin{array}{l}\text { \% of Bioactive } \\
\text { Compound/Extract } \\
\text { in the Formulation }\end{array}$ & Material Base & Methodology & $\begin{array}{c}\text { Food Application to } \\
\text { Evaluate } \\
\text { Effectiveness }\end{array}$ & $\begin{array}{c}\text { Means/Tests/Assays for } \\
\text { the Evaluation of Films } \\
\text { Effectiveness }\end{array}$ & $\begin{array}{c}\text { Main Effects/Conclusions } \\
\text { of the Study }\end{array}$ & Reference \\
\hline $\begin{array}{l}\text { Origanum vulgare L. } \\
\text { essential oil }\end{array}$ & $\begin{array}{c}0.4 \%, 0.8 \% \text { and } 1.2 \% \\
(w / v)\end{array}$ & Fish gelatin/chitosan & Casting & $\mathrm{N} / \mathrm{A}$ & $\begin{array}{l}\text { Characterization of films } \\
\text { Antimicrobial activity } \\
\text { evaluation against } S \text {. } \\
\text { aureus, L. monocytogenes, } \\
\text { S. enteritidis and E. coli }\end{array}$ & $\begin{array}{l}\text { The films were more } \\
\text { effective against } \\
\text { Gram-positive bacteria ( } S \text {. } \\
\text { aureus and L. monocytogenes) } \\
\text { decrease) in tensile strength } \\
\text { and elastic modulus } \\
\text { Increase water vapour } \\
\text { permeability in a } \\
\text { dose-dependent manner } \\
\text { Higher barrier capability } \\
\text { relative to UV light }\end{array}$ & [95] \\
\hline Quercetin & $\begin{array}{c}0,0.025 \%, 0.05 \% \text { and } \\
0.1 \%\end{array}$ & $\begin{array}{c}\text { Cassava } \\
\text { starch/gelatin }\end{array}$ & Casting & $\begin{array}{l}\text { Pork } \\
\text { Lard }\end{array}$ & $\begin{array}{c}\text { Antioxidant activity } \\
\text { assessment by DPPH } \\
\text { assay; } \\
\text { Film mechanical } \\
\text { properties determination } \\
\text { by analytic techniques; } \\
\text { Estimation of peroxide } \\
\text { value }\end{array}$ & $\begin{array}{c}\text { The films have antioxidant } \\
\text { capacity; } \\
\text { Tensile strength, water } \\
\text { solubility and water vapour } \\
\text { increasing and elongation at } \\
\text { the break of composite films } \\
\text { decreasing, at } 34 \% \text { of relative } \\
\text { humidity } \\
\text { Quercetin delayed the } \\
\text { oxidation of lard for more } \\
\text { than } 35 \text { days and redness } \\
\text { discolouration of pork }\end{array}$ & [92] \\
\hline $\begin{array}{c}\text { Feijoa (Acca } \\
\text { sellowiana (Berg) } \\
\text { Burret) pulp and } \\
\text { husk extracs }\end{array}$ & $25 \%(v / v)$ & Starch/citric pectin & Casting & $\begin{array}{c}\text { Beef } \\
\text { Bread } \\
\text { Grapes }\end{array}$ & $\begin{array}{c}\text { Films characterization; } \\
\text { Antimicrobial activity } \\
\text { against E. coli } \\
\text { (Gram-negative), } \\
\text { Salmonella } \\
\text { (Gram-negative), Shigella } \\
\text { (Gram-negative), mold } \\
\text { and yeasts } \\
\text { Lipid oxidation } \\
\text { inhibition studies }\end{array}$ & $\begin{array}{l}\text { Strong antimicrobial activity } \\
\text { in beef and bread; } \\
\text { Stabilization of lipid } \\
\text { oxidation reactions in meat } \\
\text { during six months of } \\
\text { refrigerated storage; } \\
\text { Maintenance of grapes } \\
\text { conservation for } 30 \text { days }\end{array}$ & [96] \\
\hline
\end{tabular}


Table 3. Cont.

\begin{tabular}{|c|c|c|c|c|c|c|c|}
\hline Active Compound. & $\begin{array}{l}\% \text { of Bioactive } \\
\text { Compound/Extract } \\
\text { in the Formulation }\end{array}$ & Material Base & Methodology & $\begin{array}{c}\text { Food Application to } \\
\text { Evaluate } \\
\text { Effectiveness }\end{array}$ & $\begin{array}{c}\text { Means/Tests/Assays for } \\
\text { the Evaluation of Films } \\
\text { Effectiveness }\end{array}$ & $\begin{array}{c}\text { Main Effects/Conclusions } \\
\text { of the Study }\end{array}$ & Reference \\
\hline $\begin{array}{l}\text { Persicaria minor } \\
\text { leaves ethanolic } \\
\text { extracts }\end{array}$ & $\begin{array}{c}0.4 \%, 1.0 \% \text { and } 2.0 \% \\
w / w\end{array}$ & Carrageenan & Casting & Meat patties & $\begin{array}{c}\text { Antioxidant activity } \\
\text { determination by DPPH } \\
\text { and ORAC methods; } \\
\text { Lipid degradation study } \\
\text { by TBARS assay } \\
\text { Lipid oxidation } \\
\text { evaluation through } \\
\text { malondialdehyde (MDA) }\end{array}$ & $\begin{array}{l}\text { High antioxidant activity; } \\
\text { Lower lipid deterioration } \\
\text { exhibited by } 2 \% \text { Persicaria } \\
\text { minor extract active film }\end{array}$ & [97] \\
\hline $\begin{array}{l}\text { Oregano, clove, and } \\
\text { rosemary leaves } \\
\text { essential oils }\end{array}$ & Several compositions & Starch & Extrusion & Beef & $\begin{array}{c}\text { assay; } \\
\text { Antioxidant activity } \\
\text { assessment by DPPH } \\
\text { and ORAC methods; } \\
\text { Antimicrobial activity } \\
\text { against } \\
\text { E. coli, S. aureus, } \\
\text { Lactobacillus } \\
\text { Plantarum and } \\
\text { Pseudomonas aeruginosa } \\
\text { (P. aeruginosa) during } 12 \\
\text { days of refrigerated } \\
\text { storage }\end{array}$ & $\begin{array}{l}\text { Effective inhibition of tested } \\
\text { bacteria in } 3 \% \text { or more } \\
\text { oregano essential oils; } \\
\text { Clove oils showed greater } \\
\text { antioxidant activity } \\
\text { compared to oregano and } \\
\text { rosemary essential oils, } \\
\text { retarding lipid oxidation } \\
\text { more effectively }\end{array}$ & [98] \\
\hline $\begin{array}{l}\text { Ethanolic extracts } \\
\text { from Capsicum } \\
\text { chinense Jacq. fruits }\end{array}$ & n.d. & Arrowroot starch & Casting & $\mathrm{N} / \mathrm{A}$ & $\begin{array}{c}\text { Evaluation of } \\
\text { antioxidant activity by } \\
\text { DPPH, ABTS and FRAP; } \\
\text { Characterization of films }\end{array}$ & $\begin{array}{c}\text { Increase in thickness, } \\
\text { decrease in solubility and } \\
\text { change in colour in a } \\
\text { dose-dependent manner; } \\
\text { Good antioxidant activities }\end{array}$ & [93] \\
\hline $\begin{array}{c}\text { Spent black tea } \\
\text { extract }\end{array}$ & $0.17 \%$ and $0.34 \%$ & Cassava starch & Casting & $\begin{array}{l}\text { Aqueous and fatty } \\
\text { food simulants; } \\
\text { Soybean oil }\end{array}$ & $\begin{array}{c}\text { Evaluation of } \\
\text { antioxidant activity by } \\
\text { DPPH assay and } \\
\text { determination of } \\
\text { peroxide value }\end{array}$ & $\begin{array}{l}\text { High antioxidant properties } \\
\text { due to radical scavenging } \\
\text { preventing lipid oxidation in } \\
\text { soybean oil }\end{array}$ & [99] \\
\hline
\end{tabular}




\section{Phenolic Compounds Incorporated in Gums and Starches for Preparing Active Films}

Phenolic compounds are secondary metabolites produced by plants (seeds, fruit, peels and leaves) [100] to protect them from environmental aggressions such as UV light, infections and herbivores [101]. Polyphenols have at least one aromatic ring with one or more hydroxyl groups attached and according to the number of aromatic rings and its functional group. Polyphenolic compounds are classified into phenolic acids, flavonoids, anthocyanins, stilbenes, lignans, coumarins and tannins (Figure 4) [101-103]. These compounds exhibit several biological activities such as antioxidant [103,104], antiinflammatory [105-107], antimicrobial [106] and antidiabetic [104,108] properties.

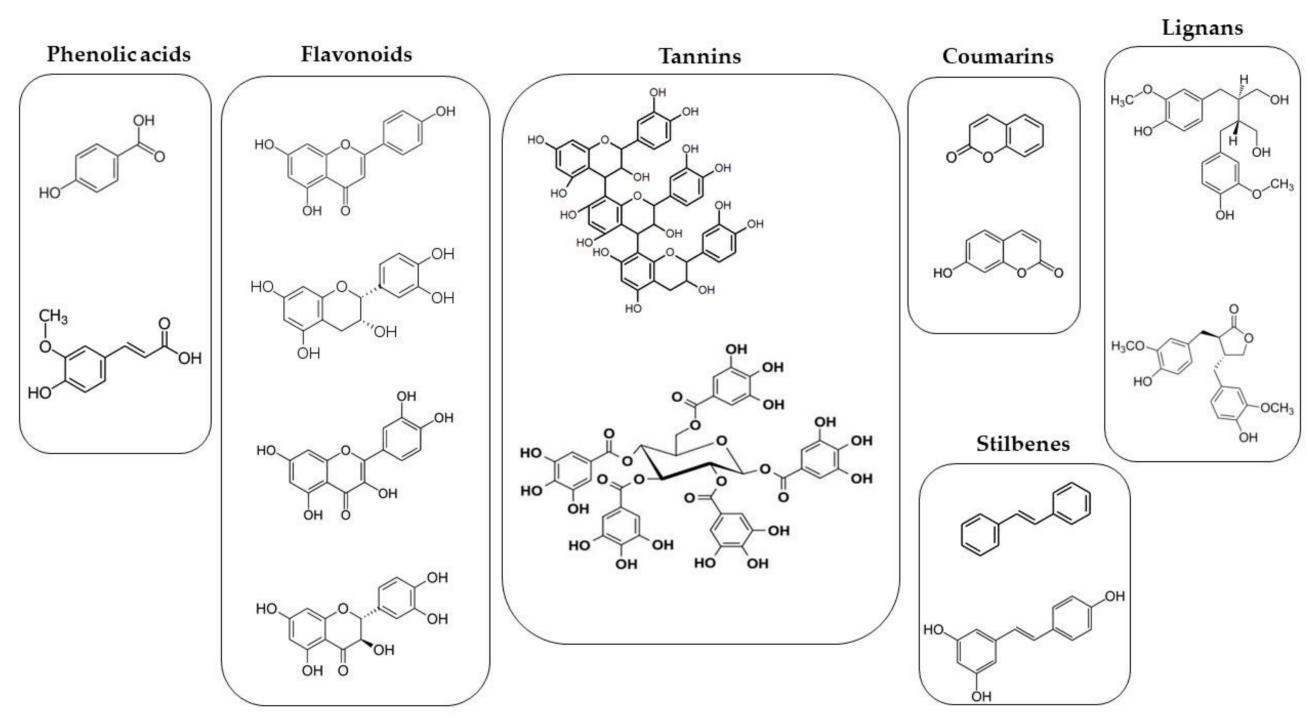

Figure 4. Examples of phenolic compounds structures presents in plant extracts (https://chem.nlm. nih.gov/chemidplus/, accessed on 10 November 2021).

Food storage is limited by enzymatic, non-enzymatic and microbial reactions that alter the quality of the food through flavour, texture and aroma changes and deterioration [108]. Intrinsic chemical reactions that occur in foods are linked to microbial contamination, as changes in $\mathrm{pH}$, temperature, light and exposure to air create favourable conditions for microbial growth. These chemical reactions are oxidation, proteolysis, putrefaction, Maillard reaction, pectin hydrolysis and hydrolytic rancidity [108].

Proteolysis occurs in nitrogen-containing compounds, where proteins are converted into small amino acids. The Maillard reaction is a non-enzymatic reaction that occurs in groups of amino acids in proteins or in amino acids present in food. This reaction is responsible for darkening colour and reducing protein solubility and is responsible for developing undesirable flavours and decreasing the nutritional properties of foods. The Maillard reaction occurs mostly in milk, dry whole eggs and breakfast cereals. Pectin hydrolysis occurs in fruits and vegetables during the ripening process or due to mechanical damages that activate indigenous pectinases, favouring microbial contamination. Moreover, pectin can be de-esterified by methyl esterase responsible for spoilage and colour change in fruit jams or jellies. Hydrolytic rancidity occurs mainly in fats, such as butter [108]. Lipid oxidation is responsible for the development of off-flavours and rancidity, the formation of toxic aldehydes and the loss of nutritional quality due to unsaturated fatty acids degradation, namely polyunsaturated fatty acid (PUFA) [109]. In addition, foods are prone to microbial contamination, also resulting in food spoilage. In order to solve these problems, synthetic preservatives, such as BHT and BHA, are commonly added to foods in order to prevent lipid oxidation and food spoilage [17,94,110-112]. However, due to the apparent toxic effects of these additives and the search for healthier food products [93], natural compounds such as polyphenols appear as an alternative to synthetic additives [17], 
serving as a valuable ally in the quality preservation of foods and extending their shelf life [103].

Antimicrobial activity of polyphenolic compounds is generally related with the induction of the leakage of cellular content; blocking DNA/RNA/protein synthesis; and, consequently, their function; modifications on membrane potential; disruption of membrane structure and function and induction of cytoplasmatic acidification; and coagulation of cytoplasmatic constituents [112]. On the other hand, most polyphenols present antioxidant properties as they can act against oxidative species such as Reactive Oxygen Species (ROS) through radical scavenging and also prevent ROS generation by iron chelation, presenting antioxidant properties [113]. In addition to its biological properties, many polyphenols have the capacity to enhance physico-chemical properties of the film or coating packages such as enhancement of its water/vapour barriers, tensile strength, colour, solubility and organoleptic characteristics [100]. Essential oils also have antimicrobial activity against bacteria and fungi. When added to films or coatings, due to its volatile compounds content, essential oils can also modify the organoleptic characteristics of foods (e.g., unpleasant odour and flavour). However, comparatively to plant extracts, the production of essential oil has lower yields and, consequently, less economic value. Thus, essential oils applications in food packaging are limited [112].

There are several studies concerning the incorporation of polyphenols in films containing polysaccharides. Cassava starch films with green tea and aqueous palm oil extracts were developed and applied in butter. The active edible starch films presented antioxidant activity decreasing the peroxide index, but in high concentrations of green tea extract polyphenols can act as pro-oxidants. Moreover, green tea and palm oil extracts reduced tensile strength and water vapour barriers [90].

Mango peel powder, a by-product, was added to starch edible films and applied on apple slices storage at a temperature of $4{ }^{\circ} \mathrm{C}$. The phenolic compounds present in mango peel powder were responsible for higher antioxidant activity. The mango peel extract also increased the resistance of edible films, maintaining the film structure as almost intact [114].

In order to preserve acidic foods and drinks (e.g., wine and juices), chitosan/genipin active edible films were developed. The authors fractionated the wine extract in three fractions and produced three active edible chitosan films: chitosan films with phenolic compounds mixture (PCM), chitosan films with anthocyanins (AN) and chitosan edible films with phenolic acids (PA). The qualitative analysis of phenolic acids fraction showed the presence of gallic ((6), Figure 5), $p$-coumaric ((3), Figure 5), trans-caftaric ((7), Figure 5), $p$-hydroxybenzoic ((5), Figure 5), caffeic ((1), Figure 5) and chlorogenic acids ((4), Figure 5), $(+)$-catechin ((23), Figure 5) and (-)-epicatechin ((24), Figure 5). The anthocyanins fraction was mainly comprised malvidin-3-glucoside ((19), Figure 5). PCM and AN active edible chitosan/genipin films showed lower solubility and, therefore, lower weight loss. Concerning antioxidant activity, PA chitosan films were the most active followed by anthocyanins and phenolic compounds mixture. Thus, this active chitosan film has potential as an acidic food preservative [115]. 


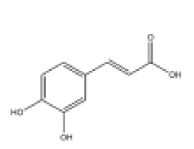

(1)<smiles>COC(=O)c1ccc(OC)cc1</smiles>

(5)

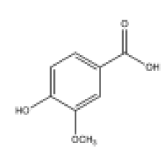

(9)

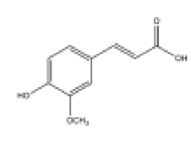

(2)

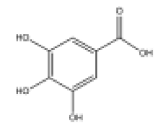

(6)

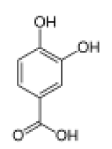

(10)

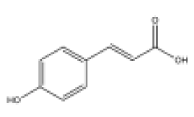

(3)

$\overbrace{O}^{C O H}$

(7)

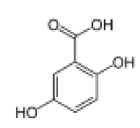

(11)<smiles>CC(CCC1CCC(C)C(C)C1)CC1CC([Al])CC(C)C1C</smiles>

(4)<smiles>O=C(O)/C=C/c1ccccc1</smiles>

(8)<smiles>O=C(/C=C/c1ccc(O)c(O)c1)OC(Cc1ccc(O)c(O)c1)C(=O)O</smiles>

(12)

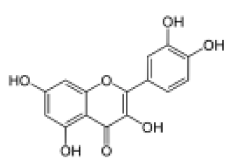

(15)

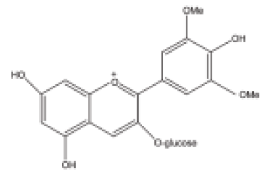

(19)

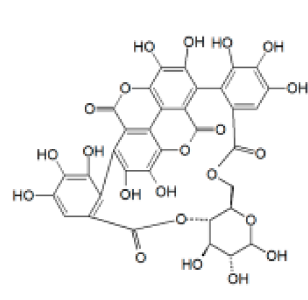

(20)

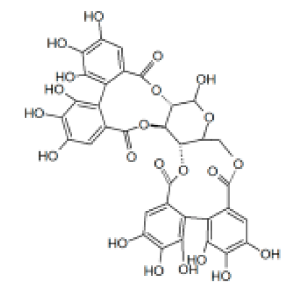

(21)

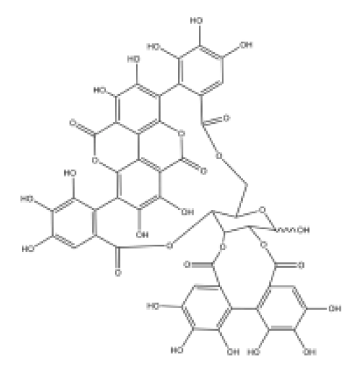

(22)

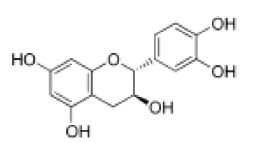

(23)

$$
\text { OH }
$$

(24)

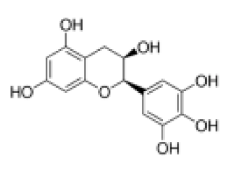

(25)

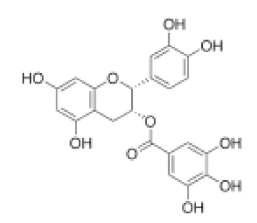

(26)

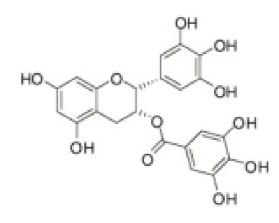

(27) 
Figure 5. Some phenolic compounds used in the described studies: (1) caffeic acid; (2) ferulic acid; (3) p-coumaric acid; (4) chlorogenic acid; (5) p-hydroxybenzoic acid; (6) gallic acid; (7) trans-caftaric acid; (8) trans-cinnamic acid; (9) vanillic acid; (10) protocatechuic acid; (11) gentisic acid; (12) rosmarinic acid; (13) ellagic acid; (14) tannic acid; (15) quercetin; (16) naringenin; (17) luteolin; (18) kaempferol; (19) malvidin-3-glucoside; (20) punicalin; (21) pedunculagin; (22) punicalagin; (23) (+)-catechin; (24) (-)-epicatechin; (25) (-)-epigallocatechin; (26) (-)-epicatechin gallate; and (27) (-)-epigallocatechin-3-gallate.

Thyme infusion was incorporated in starch and chitosan films in order to improve antioxidant activity in food preservation. The infusion has an acceptable taste and has in their composition caffeic acids and its oligomers such as flavonoid glycosides, hydroquinone derivatives and terpenoids. Rosmarinic acid is the main phenolic acid. In addition to its antioxidant activity, thyme extract changed, in a good way, the physico-chemical characteristics of films matrices. The chitosan film has higher tensile properties presenting better resistance at break and higher degrees of stiffness. However, the films become more opaque and less stretchable [116].

Gelatin/chitosan active edible films with gallic and trans-cinnamic acids were developed and tested regarding their antioxidant and antimicrobial properties. The results showed that gallic acid chitosan films were more active than trans-cinnamic acid ((8), Figure 5) in both tested activities. However, the addition of food simulants (e.g., water and ethanol) decreased phenolic acids activities. The authors concluded that gelatin/chitosan active films with gallic acid are suitable for fatty and dry foods [117]. Chitosan active edible films with pomegranate peel ethanolic extract were developed, and its antioxidant properties were evaluated. The ethanolic extract rich in flavonoids, anthocyanins, catechins, tannins (punicalin ((20), Figure 5), pedunculagin ((21), Figure 5), punicalagin ((22), Figure 5)), gallic and ellagic ((13), Figure 5) acids showed good antioxidant properties compared to BHA, which is slight lower when compared to ascorbic acids. Pomegranate extract also improved the mechanical properties of chitosan films and reduced the oxygen permeability [118], preventing lipidic oxidation reactions.

The addition of tea polyphenols (mixture of catechins) in chitosan, gelatin and starch edible films improved antioxidant and antimicrobial properties of the films. However, tea polyphenols decreased the mechanical properties of the films [91]. In another study, active edible starch-based films with potato peel phenolic extracts applied to smoked seabream revealed good antioxidant activity, good organoleptic properties, such as pleasant smell and flavour, and improved the fillets colour when compared to conventional plastic package [119].

Kaczmarek-Saczepanska and co-workers [120] have studied the incorporation of tannic, caffeic and ferulic acids in chitosan edible films. These films were irradiated with UVC light in order to sterilize them. Phenolic acids improved the physicochemical properties of films and ferulic acid showed good antimicrobial activity against $S$. aureus (Gram positive) and E. coli (Gram negative) [120].

Active chitosan coatings with clove (Eugenia caryophyllata) essential oil were tested in fresh apples. The clove essential oil composition in the weak acids' eugenol $(68.95 \%)$ and acetyl eugenol (4.88\%) enhanced chitosan solubility in aqueous solution and significantly reduced water vapour permeability. Moreover, the treated apples with active chitosan coatings delayed the spoilage process (firmness and colour) and showed antimicrobial activity against $P$. aeruginosa, S. aureus and E. coli [121]. The physicochemical and antioxidant properties of active Capsicum chinense Jacq. ethanolic extract/starch films were evaluated. Liquid chromatography coupled to mass spectrometry (LC-MS) analysis of ethanolic extract showed the presence of phenolic acids (protocatechuic ((10), Figure 5), gentisic ((11), Figure 5), caffeic, vanillic ((9), Figure 5), p-coumaric and ferulic ((2), Figure 5) acids), flavonoids (quercetin ((15), Figure 5), naringenin ((16), Figure 5), luteolin ((17), Figure 5) and kaempferol ((18), Figure 5)) and alkaloids (capsaicin and dihydrocapsaicin). Active starch films showed good antioxidant capacity attributed to phenolic compounds and increased films thickness and decreased solubility [93]. 
An extract obtained from Araucaria angustifolia (Bertol.) Kuntze cooking process, containing (+)-catechin ((23), Figure 5) and (-)-epicatechin ((24), Figure 5), was added to TPS (thermoplastic starch)/PBAT (poly (butylene-co-terephthalate) aromatic-aliphatic polyester) films. Moreover, phenolic compounds caused hydrophilic/hydrophobic alterations in matrix films and lowered its solubility, crystallinity degree and starch glass transition temperature [122], improving the flexibility of biopolymers [123].

Falcó et al. [124] studied the antiviral potential of green tea incorporated in alginate/oleic acid edible coating in strawberries and raspberries. Green tea is rich in polyphenols, mainly (-)-epicatechin, (-)-epigallocatechin ((25), Figure 5), (-)-epicatechin gallate ((26), Figure 5) and (-)-epigallocatechin-3-gallate ((27), Figure 5). Catechins are unstable at some values of $\mathrm{pH}$, and its antiviral efficacy depends on these compounds. Thus, for $\mathrm{pH}$ above 5.5 the green tea extract inhibited completely murine norovirus and hepatite A virus after storage at $25^{\circ} \mathrm{C}$. The green tea extract also revealed antioxidant activity, which was not $\mathrm{pH}$ dependent [124].

The described studies show that the incorporation of phenolic compounds in active gums or starch edible films improves, in general, the physicochemical properties of the films and coatings in addition to its antioxidant and antimicrobial activities.

\section{Intelligent and Active Starch/Gums Films with Phenolic Compounds}

While active polysaccharides films have an active function for enhancing food quality and preventing food spoilage, intelligent polysaccharides films monitor food conditions inside packaging, providing information about food safety and quality [125]. Unlike active packaging, intelligent packaging does not release its compounds into food [126]. Bio-based smart packaging present environmental and economic advantages and allow real-time monitorization, assuring food safety and quality [125]. Intelligent packaging can be classified as indicators, sensors and data carrier. Indicators provide visual, qualitative or quantitative information about food to colour change or dye diffusion. Changes in $\mathrm{pH}$ and temperature are responsible for food packaging colour change and can be identified by indicators such as freshness, microbial spoilage, gases, integrity and time-temperature indicators (TTI). The most common indicators are based in $\mathrm{pH}$ changes due to metabolite production such as n-butyrate, L-lactic acid, D-lactate, acetic acid and volatile amines [126]. The second type of intelligent packaging is sensors, which detect and register information about biological reactions. The most common sensors are biosensors that use biological or organic material that recognize the respective analyte. Some biosensors are currently commercialized to detect food pathogens. Food Sentinel System (SIRA Technologies Inc.) is a biosensor used to detect the presence of pathogens through the formation of a dark colouration band. ToxinGuard ${ }^{\circledR}$ (Toxin Alert, Canada) is a biosensor that detects specific microorganisms such as Salmonela spp., E. coli, Listeria spp. and Campylobacter spp. The third type of smart packaging includes data carriers. Data carriers do not provide quantitative or qualitative information about food products. They are responsible for identification, automation, anti-theft prevention and traceability of food products. Foods can be identified through radiofrequency identification labels (RFID), bar and QR codes [126].

Polyphenolic compounds and others present in plant extracts (e.g., chlorophyll and carotenoids) have a proper colour that, due to $\mathrm{pH}$ variations, change to another colour [125]. However, the type of phenolic compounds chosen is important for intelligent film packaging development due to their physico-chemical properties and pH-sensitive capacity. Among phenolic compounds, anthocyanins and curcumin are more suitable for smart packaging development [127].

Fernández-Marín et al. [128] developed pH sensitive intelligent films by adding curcuma oil and anthocyanins extracts into a chitosan matrix reinforced with $\alpha$-chitin nanocrystals. The essential oil of curcuma and anthocyanins extracts improved the mechanical properties of chitosan films, decreased water solubility and moisture content and blocked partially the UV/Vis light at wavelengths below $550 \mathrm{~nm}$. Moreover, these intelligent films proved to be sensible to ammonia gas and different $\mathrm{pH}$, changing the 
colour of packaging. Due to these results, intelligent active chitosan films have potential to be applied as food quality sensors [128].

Yun et al. (2019) prepared a cassava starch film with anthocyanin-rich bayberry (Myrica rubra Sieb. et Zucc.) extract (BBE), with antioxidant and $\mathrm{pH}$-sensitive properties. Phytochemical analysis of BBE was performed by HPLC-MS, identifying cyanidin-3-Oglucoside as the main anthocyanin. The addition of BBE into the film matrix improved water vapour permeability, tensile strength, UV-Vis light barrier and antioxidant properties. Relative to $\mathrm{pH}$ changes, cassava starch BBE film showed colour changes when hydrogen chloride and ammonia gases were present. The developed film was tested in pork where freshness and antioxidant capacity were evaluated. The results showed good antioxidant properties and $\mathrm{pH}$-sensitive capability [129].

Other authors developed intelligent and active $\mathrm{k}$-carrageenan films incorporated with pomegranate flesh (PFE) and peel (PPE) ethanolic extracts. PFE presented higher total anthocyanins content; therefore, it was used for intelligent packaging film. Pomegranate peel extract was rich in total phenolic compounds responsible for antioxidant and antimicrobial properties. PPE incorporation in $\mathrm{K}$-carrageenan films increased tensile strength and decreased moisture content and water vapour permeability compared with PFE films. The $\mathrm{pH}$ sensibility of films was assessed. $\mathrm{k}$-carrageenan with PFE change its colour to $\mathrm{pH}$ variation (red at $\mathrm{pH}=3$ and yellow to $\mathrm{pH}=11$ ). Both PEE and PFE $\mathrm{K}$-carrageenan films showed good antioxidant and antibacterial activities when compared to control [130].

Several concentrations of Propolis extract and anthocyanin were added to polyvinyl alcohol (PVA)-starch films in order to prepare intelligent and active films. The prepared films were tested against $E$. coli and Methicillin-resistant $S$. aureus (MRSA) in pasteurized milk. The authors of this study verified that the film containing $20 \%$ of propolis extract exhibited better mechanical strength and highest antibacterial activity. Moreover, when immersed in different solutions of $\mathrm{pH}$ from 1 to 14 , the films were responsive to these variations, changing its colour [131].

Roselle anthocyanins were used to prepare an intelligent active starch/PVA and chitosan films to monitor pork freshness. The physico-chemical properties and antioxidant activity were evaluated. The researchers observed that anthocyanins had a significant effect in the microstructure of the films, improving the compatibility of films and tensile strength. Anthocyanins Roselle extract showed good antioxidant activity and presented visible colour changes at $\mathrm{pH}$ variation $\left(\right.$ at $25^{\circ} \mathrm{C}$ ) of pork meat [132].

Anthocyanins from black soybean seed were extracted and incorporated in chitosan films. Phytochemical characterization was assessed by HPLC-PDA, and the antioxidant potential by DPPH assay was evaluated. The main identified anthocyanins were cyanidin3-O-galactoside, cyanidin-3-O-glucoside and peonidin-3-O-glucoside. Anthocyanins from black soybean extract improved water vapour and UV-vis light barrier as well the mechanical strength of the films. on the other hand, the anthocyanins extract decreased moisture content and transparency. Regarding antioxidant activity, the extract exhibited antioxidant capacity in a dose-dependent manner. By changing $\mathrm{pH}$, the films were able to colour change [133].

Intelligent and active packaging is an innovative, safe, healthy and eco-friendly method for enhancing food safety and quality, increasing food shelf life. Active and intelligent packaging possesses different functions, thus, choosing the better type of polyphenols to achieve the intended function of coating is necessary. Anthocyanins are suitable for smart packaging development while, for example, phenolic acids and flavonoids are more suitable for active packaging (due to its antioxidant and antimicrobial properties) [130].

Phenolic compounds are known to be unstable at $\mathrm{pH}$ and temperature variations and UV-vis light exposure [134]. In order to provide structural stability and to enhance biological properties, phenolic compounds are encapsulated and posteriorly added to starch/gums edible films [134]. Zhang et al. [134] studied $\beta$-chitosan nanoparticles of several sizes in order to encapsulate catechins by ionic gelation. The authors evaluated the antimicrobial properties of the developed catechins nanoparticles against $E$. coli and 
Listeria innocua (L. innocua). The smaller nanoparticles exhibited higher antibacterial activity. Regarding catechin nanoparticles stability, they presented higher stability in the $\mathrm{pH}$ range 2.0-4.5, with nanoparticle precipitation occurring at $\mathrm{pH}$ above 5.0.

There are a few studies about the encapsulation of phenolic compounds and the incorporation of these nanoparticles in starch/gums edible films. Nanoencapsulation of polyphenols for food packaging application is an emerging area.

Polysaccharide films are a good alternative to common packaging, being healthier, ecofriendly and economical. In order to enhance food quality and safety, phenolic compounds could be used as an alternative to decrease or substitute synthetic preservatives, as well food indicators. However, polysaccharide matrices present some disadvantages relative to common packaging such as instable tensile strength, water-vapour barriers, solubility and others. The addition of phenolic compounds, in some cases, improves the physico-chemical properties of film matrix. In addition, in order to enhance film resistance, plasticizers are added. Polyphenols are obtained from natural sources but it is also from by-products (from agricultural wastes, for example) [130], where the latter is more economic. The diversified structures of polyphenols allow them to have two fundamental roles in edible packaging: used in active edible packaging due to their biological properties, namely antioxidant and antimicrobial; and in intelligent packaging, such as $\mathrm{pH}$ indicators, controlling and monitoring the quality and safety of food. Moreover, polyphenols have the capability to modulate the physico-chemical properties of starch and gums films. In some cases, they improve the mechanical characteristics of films as well barriers properties. Most phenolic compounds have no toxicity in human health [135]. On the other hand, phenolic compounds are unstable with respect to variations in $\mathrm{pH}$, temperature and UV light exposure; thus, care must be taken when preparing extracts and incorporating them into films. The studies described in this review also show that some polyphenols can act as pro-oxidants when they are above certain concentrations.

\section{Legislation}

In the European Union, the legislation for food packaging is described in Regulation (EC) No 1935/2004 and its amendments. According to article 3 of this regulation [136], food packaging should not release any constituents for the food at a toxic level for humans as well as at levels that result in physicochemical and organoleptic changes in food composition, and they must have the correct information about the contained product [5]. For active and intelligent materials, the rules are described in Commission Regulation (EC) No $450 / 2009[126,137]$ and its amendments. The active materials can release substances into the food acting as preservative or absorb substances from food packaging, such as liquids and gases (e.g., oxygen) [136]. In United States, the approval for food packaging is the responsibility of the Food and Drug Administration (FDA). According to this entity, for the approval of an edible packaging, the packaging must not only be safe but also listed as GRAS and used according with Good Manufacturing Practices (GMP) [138]. According to the regulations EU no. 10/2011, on plastic materials, and EC 450/2009, on active and intelligent materials, if components are not available in the positive list of the regulation EC no. 10/2011 (the list of approved compounds to be used in the manufacture of plasticbased packaging) and not specifically recognized as a food additive (e.g., catechins and caffeine), they must be below $10 \mu \mathrm{g}$ per $\mathrm{kg}$ of food or food simulant [112]. When the biopolymer material is not listed as GRAS, the producer must apply for its approval, demonstrating product safety. In some cases, active edible packaging has essential oils in its composition; therefore, its toxicity and allergenic effects must be evaluated in order to grant food safety [138].

Due to the recent search and increase in natural preservatives use, the European legislation (EC/1334/2008) [139] has been amended in order to include information regarding natural extracts. According to FDA, natural compounds are accepted as safe and are allowed for food use in the case of the following: the dose required to produce the intended 
effect is minimum, within the good manufacturing practice principles, and is applied in its forms (e.g., plant extracts and essential oils) [112].

The development of edible films or coatings is encouraged by the US Environmental Protection Agency's (EPA) due to its environmental properties. This agency aims to design new food packaging with less environmental toxic materials and its possibility to reuse or compost [138]. The International Organization for Standardization (ISO) establishes legislation for the production, distribution and use of packaging materials such as ISO 18604:2013(E). Moreover, this organization also has regulations concerning the reusability and biodegradability properties of packaging materials [5].

\section{Conclusions}

Natural polysaccharides are good alternatives to conventional packaging as they are generally more economical, environmentally friendly and biodegradable (at least to some extent). These polysaccharides form an edible matrix capable of coating food, thereby reducing the use of synthetic and non-biodegradable packaging. Given the demand for healthier and less processed foods, the addition of natural compounds, such as phenolic compounds, can reduce or replace synthetic additives, preventing lipid oxidation and contamination by microorganisms, improving the preservation of food quality and extending the expiration date. In addition to these biological properties, phenolic compounds also modulate the physical and chemical properties of films, which can improve or worsen them. More studies are needed in order to improve the physical properties of edible films or coatings. Active films or coatings containing polyphenols are an alternative with less environmental impact and also healthier for human consumption.

\section{Future Perspectives}

More studies are needed to improve the physico-chemical characteristics of films without plasticizer addition. Due to their diversity, phenolic compounds must be studied in order to improve the physico-chemical structure of polysaccharide films and achieve better biological properties. Polyphenols present in plant extracts are mostly glycosylated. Some studies mentioned here refer to genins as active compounds in the tested films. Thus, it is important to assess whether glycosylation and its degree interfere with the biological properties (antioxidant and antimicrobial) and physicochemical characteristics of the films.

Author Contributions: Conceptualization, F.R. and A.S.S.; methodology, and formal analysis, S.P. and A.F.; writing-S.P.; writing-review and editing, A.F., A.S.S. and F.R.; supervision, F.R.; funding acquisition, F.R. and A.S.S. All authors have read and agreed to the published version of the manuscript.

Funding: This research was funded by PT national funds (FCT/MCTES, Fundação para a Ciência e Tecnologia and Ministério da Ciência, Tecnologia e Ensino Superior) through grants UIDB/50006/2020 and UIDB/00211/2020.

Institutional Review Board Statement: Not applicable.

Informed Consent Statement: Not applicable.

Data Availability Statement: Data are contained within the article.

Conflicts of Interest: The authors declare no conflict of interest.

\section{References}

1. Adeyeye, O.A.; Sadiku, E.R.; Babu Reddy, A.; Ndamase, A.S.; Makgatho, G.; Sellamuthu, P.S.; Perumal, A.B.; Nambiar, R.B.; Fasiku, V.O.; Ibrahim, I.D.; et al. The Use of Biopolymers in Food Packaging. In Green Biopolymers and Their Nanocomposites. Materials Horizons: From Nature to Nanomaterials; Gnanasekaran, D., Ed.; Springer: Singapore, 2019; pp. 137-158. [CrossRef]

2. Mironescu, M.; Lazea-Stoyanova, A.; Barbinta-Patrascu, M.E.; Virchea, L.-I.; Rexhepi, D.; Mathe, E.; Georgescu, C. Green design of novel starch-based packaging materials sustaining human and environmental health. Polymers 2021, 13, 1190. [CrossRef] [PubMed]

3. Porta, R.; Sabbah, M.; Pierro, P. Di Biopolymers as Food Packaging Materials. Int. J. Mol. Sci. 2020, 21, 4942. [CrossRef] [PubMed] 
4. Asgher, M.; Qamar, S.A.; Bilal, M.; Iqbal, H.M.N. Bio-based active food packaging materials: Sustainable alternative to conventional petrochemical-based packaging materials. Food Res. Int. 2020, 137, 109625. [CrossRef] [PubMed]

5. Díaz-Montes, E.; Castro-Muñoz, R. Edible films and coatings as food-quality preservers: An overview. Foods 2021, 10, 249. [CrossRef]

6. Nilsen-Nygaard, J.; Fernández, E.N.; Radusin, T.; Rotabakk, B.T.; Sarfraz, J.; Sharmin, N.; Sivertsvik, M.; Sone, I.; Pettersen, M.K. Current status of biobased and biodegradable food packaging materials: Impact on food quality and effect of innovative processing technologies. Compr. Rev. Food Sci. Food Saf. 2021, 20, 1333-1380. [CrossRef]

7. Samsudin, H.; Hani, N.M. Use of starch in food packaging. Starch-Based Mater. Food Packag. Process. Charact. Appl. 2017, 229-256. [CrossRef]

8. Sahu, M.; Sahoo, P.K. Bio polymers: Sustainable alternative for food packaging. Int. J. Eng. Manag. Res. 2017, $28-32$.

9. Grujić, R.; Vujadinović, D.; Savanović, D. Biopolymers as food packaging materials. Adv. Appl. Ind. Biomater. 2017, 139-160. [CrossRef]

10. Ferreira, A.R.V.; Alves, V.D.; Coelhoso, I.M. Polysaccharide-based membranes in food packaging applications. Membranes 2016, 6, 22. [CrossRef]

11. Shendurse, A. Milk protein based edible films and coatings-preparation, properties and food applications. J. Nutr. Health Food Eng. 2018, 8, 219-226. [CrossRef]

12. Tavassoli-Kafrani, E.; Gamage, M.V.; Dumée, L.F.; Kong, L.; Zhao, S. Edible films and coatings for shelf life extension of mango: A review. Crit. Rev. Food Sci. Nutr. 2020, 1-26. [CrossRef]

13. Sharma, H.P.; Chaudhary, V.; Kumar, M. Importance of edible coating on fruits and vegetables: A review. J. Pharmacogn. Phytochem. 2019, 8, 4104-4110.

14. Benbettaïeb, N.; Debeaufort, F.; Karbowiak, T. Bioactive edible films for food applications: Mechanisms of antimicrobial and antioxidant activity. Crit. Rev. Food Sci. Nutr. 2018, 59, 3431-3455. [CrossRef]

15. Han, J.H. Edible films and coatings: A review. Innov. Food Packag. 2014, 213-255. [CrossRef]

16. Lazaridou, A.; Biliaderis, C.G. Edible films and coatings with pectin. Pectin Technol. Physiol. Prop. 2020, 99-123. [CrossRef]

17. Pandey, H.; Kumar, S. Butylated hydroxytoluene and Butylated hydroxyanisole induced cyto-genotoxicity in root cells of Allium cepa L. Heliyon 2021, 7, e07055. [CrossRef]

18. Quirós-Sauceda, A.E.; Ayala-Zavala, J.F.; Olivas, G.I.; González-Aguilar, G.A. Edible coatings as encapsulating matrices for bioactive compounds: A review. J. Food Sci. Technol. 2014, 51, 1674. [CrossRef]

19. Pop, O.L.; Pop, C.R.; Dufrechou, M.; Vodnar, D.C.; Socaci, S.A.; Dulf, F.V.; Minervini, F.; Suharoschi, R. Edible films and coatings functionalization by probiotic incorporation: A review. Polymers 2019, 12, 12. [CrossRef]

20. Silva-Weiss, A.; Ihl, M.; Sobral, P.J.A.; Gómez-Guillén, M.C.; Bifani, V. Natural additives in bioactive edible films and coatings: Functionality and applications in foods. Food Eng. Rev. 2013, 5, 200-216. [CrossRef]

21. Eça, K.S.; Sartori, T.; Menegalli, F.C. Films and edible coatings containing antioxidants-A review. Braz. J. Food Technol. 2014, 17, 98-112. [CrossRef]

22. Alizadeh-Sani, M.; Ehsani, A.; Moghaddas Kia, E.; Khezerlou, A. Microbial gums: Introducing a novel functional component of edible coatings and packaging. Appl. Microbiol. Biotechnol. 2019, 103, 6853-6866. [CrossRef]

23. da Silva, D.A.; Aires, G.C.M.; Pena, R.D.S. Gums—Characteristics and Applications in the Food Industry. In Innovation in the Food Sector through the Valorization of Food and Agro-Food By-Products; IntechOpen: Rijeka, Croatia, 2020. [CrossRef]

24. Saha, A.; Tyagi, S.; Gupta, R.K.; Tyagi, Y.K. Natural gums of plant origin as edible coatings for food industry applications. Crit. Rev. Biotechnol. 2017, 37, 959-973. [CrossRef]

25. Katzbauer, B. Properties and applications of xanthan gum. Polym. Degrad. Stab. 1998, 59, 81-84. [CrossRef]

26. Yousuf, B.; Wu, S.; Gao, Y. Characteristics of karaya gum based films: Amelioration by inclusion of schisandra chinensis oil and its oleogel in the film formulation. Food Chem. 2021, 345, 128859. [CrossRef]

27. Khezerlou, A.; Zolfaghari, H.; Banihashemi, S.A.; Forghani, S.; Ehsani, A. Plant gums as the functional compounds for edible films and coatings in the food industry: A review. Polym. Adv. Technol. 2021, 32, 2306-2326. [CrossRef]

28. Soleimani-Rambod, A.; Zomorodi, S.; Raeisi, S.N.; Asl, A.K.; Shahidi, S.-A. The effect of xanthan gum and flaxseed mucilage as edible coatings in cheddar cheese during ripening. Coatings 2018, 8, 80. [CrossRef]

29. Lochhead, R.Y. The use of polymers in cosmetic products. Cosmet. Sci. Technol. Theor. Princ. Appl. 2017, 171-221. [CrossRef]

30. Becker, A.; Katzen, F.; Pühler, A.; Ielpi, L. Xanthan gum biosynthesis and application: A biochemical/genetic perspective. Appl. Microbiol. Biotechnol. 1998, 50, 145-152. [CrossRef]

31. Mortensen, A.; Aguilar, F.; Crebelli, R.; Di Domenico, A.; Frutos, M.J.; Galtier, P.; Gott, D.; Gundert-Remy, U.; Lambré, C.; Leblanc, J.C.; et al. Re-evaluation of xanthan gum (E 415) as a food additive. EFSA J. 2017, 15, e04646. [CrossRef]

32. Bampidis, V.; Azimonti, G.; de Bastos, M.L.; Christensen, H.; Dusemund, B.; Fašmon Durjava, M.; Kouba, M.; López-Alonso, M.; López Puente, S.; Marcon, F.; et al. Safety and efficacy of an additive consisting of xanthan gum produced by Xanthomonas campestris strains for all animal species (Biopolymer International). EFSA J. 2021, 19, e06710. [CrossRef]

33. de Boer, F.Y.; Imhof, A.; Velikov, K.P. Encapsulation of colorants by natural polymers for food applications. Color. Technol. 2019, 135, 183-194. [CrossRef]

34. Salehi, F. Edible coating of fruits and vegetables using natural gums: A review. Int. J. Fruit Sci. 2020, 20, S570-S589. [CrossRef] 
35. Zambrano-Zaragoza, M.L.; Quintanar-Guerrero, D.; Del Real, A.; Piñon-Segundo, E.; Zambrano-Zaragoza, J.F. The release kinetics of $\beta$-carotene nanocapsules/xanthan gum coating and quality changes in fresh-cut melon (cantaloupe). Carbohydr. Polym. 2017, 157, 1874-1882. [CrossRef] [PubMed]

36. Lima, M.D.M.; Carneiro, L.C.; Machado, M.R.G.; Dias, A.R.G.; Zavareze, E.D.R.; Prentice, C.; Moreira, A.D.S. Application of films based on chitosan and xanthan gum in refrigerated fish conservation. Brazilian Arch. Biol. Technol. 2020, 63, 10. [CrossRef]

37. Mohamed, A.; Aboul-Anean, H.; Hassan, M. Utilization of edible coating in extending the shelf life of minimally processed prickly pear. J. Appl. Sci. Res. 2013, 9, 1202-1208.

38. Mei, Y.; Zhao, Y.; Yang, J.; Furr, H.C. Using edible coating to enhance nutritional and sensory qualities of baby carrots. J. Food Sci. 2002, 67, 1964-1968. [CrossRef]

39. Cerqueira, M.A.; Bourbon, A.I.; Pinheiro, A.C.; Martins, J.T.; Souza, B.W.S.; Teixeira, J.A.; Vicente, A.A. Galactomannans use in the development of edible films/coatings for food applications. Trends Food Sci. Technol. 2011, 22, 662-671. [CrossRef]

40. Martins, J.T.; Cerqueira, M.A.; Souza, B.W.S.; Avides, M.D.C.; Vicente, A.A. Shelf life extension of ricotta cheese using coatings of galactomannans from nonconventional sources incorporating nisin against listeria monocytogenes. J. Agric. Food Chem. 2010, 58, 1884-1891. [CrossRef]

41. Arfat, Y.A.; Ejaz, M.; Jacob, H.; Ahmed, J. Deciphering the potential of guar gum/Ag-Cu nanocomposite films as an active food packaging material. Carbohydr. Polym. 2017, 157, 65-71. [CrossRef]

42. Ruelas-Chacon, X.; Contreras-Esquivel, J.C.; Montañez, J.; Aguilera-Carbo, A.F.; Reyes-Vega, M.L.; Peralta-Rodriguez, R.D.; Sanchéz-Brambila, G. Guar gum as an edible coating for enhancing shelf-life and improving postharvest quality of roma tomato (Solanum lycopersicum L.). J. Food Qual. 2017, 2017, 8608304. [CrossRef]

43. Pérez, D.A.; Gómez, J.M.; Castellanos, D.A. Combined modified atmosphere packaging and guar gum edible coatings to preserve blackberry (Rubus glaucus Benth). Food Sci. Technol. Int. 2020, 27, 353-365. [CrossRef]

44. Naeem, A.; Abbas, T.; Ali, T.M.; Hasnain, A. Application of guar gum-based edible coatings supplemented with spice extracts to extend post-harvest shelf life of lemon (Citrus limon). Qual. Assur. Saf. Crop. Foods 2019, 11, 241-250. [CrossRef]

45. Kumar, R.; Dongariyal, A.; Rai, R.; Kumar Arya, M.; Mishra, N. Effect of edible coating and packaging on postharvest life and quality of litchi (Litchi chinensis Sonn.) fruits during storage. J. Pharmacogn. Phytochem. 2020, 9, 3018-3023.

46. Minh, N.P.; Pham, V.T.; Van Tuan, T.; Tuyen, T.T.; Mai, D.K. Application of guar gum as edible coating to prolong shelf life of red chilli pepper (Capsicum frutescens L.) fruit during preservation-ProQuest. J. Pharm. Sci. Res. 2019, 11, 1474-1478.

47. Ali, A.; Maqbool, M.; Ramachandran, S.; Alderson, P.G. Gum arabic as a novel edible coating for enhancing shelf-life and improving postharvest quality of tomato (Solanum lycopersicum L.) fruit. Postharvest Biol. Technol. 2010, 58, 42-47. [CrossRef]

48. Murmu, S.B.; Mishra, H.N. Optimization of the arabic gum based edible coating formulations with sodium caseinate and tulsi extract for guava. LWT 2017, 80, 271-279. [CrossRef]

49. Valiathan, S.; Athmaselvi, K.A. Gum arabic based composite edible coating on green chillies. Int. Agrophys. 2018, 32, 193-202. [CrossRef]

50. Saleem, M.S.; Ejaz, S.; Anjum, M.A.; Nawaz, A.; Naz, S.; Hussain, S.; Ali, S.; Canan, İ. Postharvest application of gum arabic edible coating delays ripening and maintains quality of persimmon fruits during storage. J. Food Process. Preserv. 2020, 44 , e14583. [CrossRef]

51. LL, D.; JM, N.; WM, J.; SM, R. Effect of edible gum Arabic coating on the shelf life and quality of mangoes (Mangifera indica) during storage. J. Food Sci. Technol. 2020, 57, 79-85. [CrossRef]

52. Mohebbi, M.; Ansarifar, E.; Hasanpour, N.; Amiryousefi, M.R. Suitability of aloe vera and gum tragacanth as edible coatings for extending the shelf life of button mushroom. Food Bioprocess Technol. 2011, 5, 3193-3202. [CrossRef]

53. Ziaolhagh, S.H.; Kanani, S. Extending the shelf life of apricots by using gum tragacanth-chitosan edible coating. J. Agr. Sci. Tech 2021, 23, 319-331.

54. Ali, S.; Anjum, M.A.; Nawaz, A.; Naz, S.; Ejaz, S.; Sardar, H.; Saddiq, B. Tragacanth gum coating modulates oxidative stress and maintains quality of harvested apricot fruits. Int. J. Biol. Macromol. 2020, 163, 2439-2447. [CrossRef] [PubMed]

55. Rojas-Argudo, C.; del Río, M.A.; Pérez-Gago, M.B. Development and optimization of locust bean gum (LBG)-based edible coatings for postharvest storage of "Fortune" mandarins. Postharvest Biol. Technol. 2009, 52, 227-234. [CrossRef]

56. Hashemi, S.M.B.; Jafarpour, D. The efficacy of edible film from Konjac glucomannan and saffron petal extract to improve shelf life of fresh-cut cucumber. Food Sci. Nutr. 2020, 8, 3128. [CrossRef]

57. Barion, G.C.; Vital, A.C.P.; Matumoto-Pintro, P.T.; Rosa, C.I.L.F. Influence of glucomannan edible coating in guava quality during storage. Res. Soc. Dev. 2020, 9, e2639108432. [CrossRef]

58. Morakot, N.; Vatanyoopaisarn, S.; Thumthanaruk, B.; Wongsa, J.; Puttanlek, C.; Uttapap, D.; Lamsal, B.P.; Rungsardthong, V. Effect of glucomannan and potassium sorbate on quality and shelf life of fresh-cut cantaloupe. Sci. Eng. Health Stud. 2020, 14, 123-131. [CrossRef]

59. Danalache, F.; Carvalho, C.Y.; Alves, V.D.; Moldão-Martins, M.; Mata, P. Optimisation of gellan gum edible coating for ready-to-eat mango (Mangifera indica L.) bars. Int. J. Biol. Macromol. 2016, 84, 43-53. [CrossRef]

60. Mahfoudhi, N.; Chouaibi, M.; Hamdi, S. Effectiveness of almond gum trees exudate as a novel edible coating for improving postharvest quality of tomato (Solanum lycopersicum L.) fruits. Food Sci. Technol. Int. 2014, 20, 33-43. [CrossRef]

61. Galus, S.; Kibar, E.A.A.; Gniewosz, M.; Kraśniewska, K. Novel materials in the preparation of edible films and coatings-A review. Coatings 2020, 10, 674. [CrossRef] 
62. Mahfoudhi, N.; Hamdi, S. Use of almond gum and gum arabic as novel edible coating to delay postharvest ripening and to maintain sweet cherry (Prunus avium) quality during storage. J. Food Process. Preserv. 2015, 39, 1499-1508. [CrossRef]

63. Lauer, M.K.; Smith, R.C. Recent advances in starch-based films toward food packaging applications: Physicochemical, mechanical, and functional properties. Compr. Rev. Food Sci. Food Saf. 2020, 19, 3031-3083. [CrossRef]

64. Sapper, M.; Chiralt, A. Starch-based coatings for preservation of fruits and vegetables. Coatings 2018, 8, 152. [CrossRef]

65. Sanyang, M.L.; Ilyas, R.A.; Sapuan, S.M.; Jumaidin, R. Sugar palm starch-based composites for packaging applications. In Bionanocomposites for Packaging Applications; Springer: Cham, Switzerland, 2017; pp. 125-147. [CrossRef]

66. Hatmi, R.U.; Apriyati, E.; Cahyaningrum, N. Edible coating quality with three types of starch and sorbitol plasticizer. E3S Web Conf. EDP Sci. 2020, 142, 02003. [CrossRef]

67. Sadeghizadeh-Yazdi, J.; Habibi, M.; Kamali, A.A.; Banaei, M. Application of edible and biodegradable starch-based films in food packaging: A systematic review and meta-analysis. Curr. Res. Nutr. Food Sci. 2019, 7, 624-637. [CrossRef]

68. Liu, Z. Edible films and coatings from starches. Innov. Food Packag. 2005, 318-337. [CrossRef]

69. Shaikh, S.; Yaqoob, M.; Aggarwal, P. An overview of biodegradable packaging in food industry. Curr. Res. Food Sci. 2021, 4, 503-520. [CrossRef]

70. Hernández-Guerrero, S.E.; Balois-Morales, R.; Palomino-Hermosillo, Y.A.; López-Guzmán, G.G.; Berumen-Varela, G.; BautistaRosales, P.U.; Alejo-Santiago, G. Novel edible coating of starch-based stenospermocarpic mango prolongs the shelf life of mango "ataulfo" fruit. J. Food Qual. 2020, 2020, 1320357. [CrossRef]

71. Razak, A.S.; Lazim, A.M. Starch-based edible film with gum arabic for fruits coating. AIP Conf. Proc. 2015, 1678, 050020. [CrossRef]

72. Camatari, F.O.D.S.; Santana, L.C.L.D.A.; Carnelossi, M.A.G.; Alexandre, A.P.S.; Nunes, M.L.; Goulart, M.O.F.; Narain, N.; Silva, M.A.A.P.D. Impact of edible coatings based on cassava starch and chitosan on the post-harvest shelf life of mango (Mangifera indica) 'Tommy Atkins' fruits. Food Sci. Technol. 2017, 38, 86-95. [CrossRef]

73. Kerdchoechuen, O.; Laohakunjit, N.; Tussavil, P.; Kaisangsri, N.; Matta, F.B. Effect of starch-based edible coatings on quality of minimally processed pummelo (Citrus maxima merr.). Int. J. Fruit Sci. 2011, 11, 410-423. [CrossRef]

74. Soto-Muñoz, L.; Palou, L.; Argente-Sanchis, M.; Ramos-López, M.A.; Pérez-Gago, M.B. Optimization of antifungal edible pregelatinized potato starch-based coating formulations by response surface methodology to extend postharvest life of 'Orri' mandarins. bioRxiv 2020, 288, 110394. [CrossRef]

75. Kasim, R.; Kasim, M.U. The effect of tapioca-starch edible coating on quality of fresh-cut cauliflower during storage. In Proceedings of the 3rd International Symposium for Agriculture and Food-ISAF, Ohrid, North Macedonia, 18-20 October 2017.

76. Cortés Rodríguez, M.; Villegas Yépez, C.; Gil González, J.H.; Ortega-Toro, R. Effect of a multifunctional edible coating based on cassava starch on the shelf life of Andean blackberry. Heliyon 2020, 6, e03974. [CrossRef] [PubMed]

77. Bello-Lara, J.E.; Balois-Morales, R.; Juárez-López, P.; Alia-Tejacal, I.; Peña-Valdivia, C.B.; Jiménez-Zurita, J.O.; Sumaya-Martínez, M.T.; Jiménez-Ruíz, E.I.; Bello-Lara, J.E.; Balois-Morales, R.; et al. Coatings based on starch and pectin from 'Pear' banana (Musa ABB), and chitosan applied to postharvest 'Ataulfo' mango fruit. Rev. Chapingo. Ser. Hortic. 2016, 22, 209-218. [CrossRef]

78. Basiak, E.; Geyer, M.; Debeaufort, F.; Lenart, A.; Linke, M. Relevance of interactions between starch-based coatings and plum fruit surfaces: A physical-chemical analysis. Int. J. Mol. Sci. 2019, 20, 2220. [CrossRef]

79. Kathiresan, S.; Lasekan, O. Effects of glycerol and stearic acid on the performance of chickpea starch-based coatings applied to fresh-cut papaya. CyTA-J. Food 2019, 17, 365-374. [CrossRef]

80. Ojeda, G.A.; Arias Gorman, A.M.; Sgroppo, S.C.; Zaritzky, N.E. Application of composite cassava starch/chitosan edible coating to extend the shelf life of black mulberries. J. Food Process. Preserv. 2021, 45, e15073. [CrossRef]

81. Adjouman, Y.D.; Nindjin, C.; Kouassi, K.N.; Tetchi, F.A.; Amani, G.G.; Sindic, M. Effect of edible coating based on improved cassava starch on post-harvest quality of fresh tomatoes (Solanum lycopersicum L.). Int. J. Nutr. Sci. Food Technol. 2018, 4, 1-10.

82. Chinma, C.E.; Ariahu, C.C.; Abu, J.Q. Shelf life extension of toasted groundnuts through the application of cassava starch and soy protein-based edible coating. Niger. Food J. 2014, 32, 133-138. [CrossRef]

83. Henrique, G.; Guimarães, C.; Lima Dantas, R.; Bezerra De Sousa, A.S.; Soares, L.G.; De Sá Melo, R.; Sousa Da Silva, R.; Lima, R.P.; Nunes Mendonça, R.M.; Beaudry, R.M.; et al. African journal of agricultural research impact of cassava starch-alginate based coatings added with ascorbic acid and elicitor on quality and sensory attributes during pineapple storage. Afr. J. Agric. Res. 2017, 12, 664-673. [CrossRef]

84. Silva, O.A.; Pellá, M.C.G.; Friedrich, J.C.C.; Pellá, M.G.; Beneton, A.G.; Faria, M.G.I.; Colauto, G.A.L.; Caetano, J.; Simões, M.R.; Dragunski, D.C. Effects of a native cassava starch, chitosan, and gelatin-based edible coating over guavas (Psidium guajava L.). ACS Food Sci. Technol. 2021, 1, 1247-1253. [CrossRef]

85. Eom, H.; Chang, Y.; sil Lee, E.; Choi, H.D.; Han, J. Development of a starch/gum-based edible coating for rice cakes to retard retrogradation during storage. LWT 2018, 97, 516-522. [CrossRef]

86. Omid Jeivan, A.; Taghizadeh, M.; Yavarmanesh, M. Optimization of edible coating based on modified potato starch and rice bran oil and evaluation of its effect on grape's shelf life. Innov. Food Technol. 2021, 8, 273-294. [CrossRef]

87. Ma, Y.; Zhao, Y.; Xie, J.; Sameen, D.E.; Ahmed, S.; Dai, J.; Qin, W.; Li, S.; Liu, Y. Optimization, characterization and evaluation of papaya polysaccharide-corn starch film for fresh cut apples. Int. J. Biol. Macromol. 2021, 166, 1057-1071. [CrossRef]

88. Nogueira, G.F.; de Oliveira, R.A.; Velasco, J.I.; Fakhouri, F.M. Methods of incorporating plant-derived bioactive compounds into films made with agro-based polymers for application as food packaging: A brief review. Polymers 2020, 12, 2518. [CrossRef] 
89. Ribeiro, A.M.; Estevinho, B.N.; Rocha, F. Preparation and incorporation of functional ingredients in edible films and coatings. Food Bioprocess Technol. 2020, 14, 209-231. [CrossRef]

90. Perazzo, K.K.N.C.L.; Conceição, A.C.D.V.; dos Santos, J.C.P.; de Assis, D.J.; Souza, C.O.; Druzian, J.I. Properties and antioxidant action of actives cassava starch films incorporated with green tea and palm oil extracts. PLoS ONE 2014, 9, e105199. [CrossRef]

91. Feng, M.; Yu, L.; Zhu, P.; Zhou, X.; Liu, H.; Yang, Y.; Zhou, J.; Gao, C.; Bao, X.; Chen, P. Development and preparation of active starch films carrying tea polyphenol. Carbohydr. Polym. 2018, 196, 162-167. [CrossRef]

92. Tongdeesoontorn, W.; Mauer, L.J.; Wongruong, S.; Sriburi, P.; Reungsang, A.; Rachtanapun, P. Antioxidant films from cassava starch/gelatin biocomposite fortified with quercetin and TBHQ and their applications in food models. Polymers 2021, 13, 1117. [CrossRef]

93. Santos, L.S.; Fernandes, C.C.; Santos, L.S.; de Deus, I.P.B.; de Sousa, T.L.; Miranda, M.L.D. Ethanolic extract from Capsicum chinense Jacq. ripe fruits: Phenolic compounds, antioxidant activity and development of biodegradable films. Food Sci. Technol. 2020, 41, 497-504. [CrossRef]

94. Romani, V.P.; Hernández, C.P.; Martins, V.G. Pink pepper phenolic compounds incorporation in starch/protein blends and its potential to inhibit apple browning. Food Packag. Shelf Life 2018, 15, 151-158. [CrossRef]

95. Hosseini, S.F.; Rezaei, M.; Zandi, M.; Farahmandghavi, F. Bio-based composite edible films containing Origanum vulgare L. essential oil. Ind. Crops Prod. 2015, 67, 403-413. [CrossRef]

96. Sganzerla, W.G.; da Rosa, C.G.; da Silva, A.P.G.; Ferrareze, J.P.; Azevedo, M.S.; Forster-Carneiro, T.; Nunes, M.R.; de Lima Veeck, A.P. Application in situ of biodegradable films produced with starch, citric pectin and functionalized with feijoa (Acca sellowiana (Berg) Burret) extracts: An effective proposal for food conservation. Int. J. Biol. Macromol. 2021, 189, 544-553. [CrossRef] [PubMed]

97. Yahaya, W.A.W.; Yazid, N.A.; Azman, N.A.M.; Almajano, M.P. Antioxidant activities and total phenolic content of malaysian herbs as components of active packaging film in beef patties. Antioxidants 2019, 8, 204. [CrossRef] [PubMed]

98. Cestari, L.A.; Scapim, M.R.D.S.; Madrona, G.S.; Yamashita, F.; Biondo, P.B.F.; Carvalho, V.M.; Bonin, E.; Prado, I.N.D. Production, antioxidant characterization and application of active starch-based films containing essential oils for beef packaging. Res. Soc. Dev. 2021, 10, e4310816903. [CrossRef]

99. Rajapaksha, S.W.; Shimizu, N. Development and characterization of functional starch-based films incorporating free or microencapsulated spent black tea extract. Molecules 2021, 26, 3898. [CrossRef]

100. Kola, V. Plant Extracts as Additives in Biodegradable Films and Coatings in Active Food Packaging: Effects and Applications. Master's Thesis, Faculty of Sciences and Technology of University of Algarve, Algarve, Portugal, 2020.

101. Lin, D.; Xiao, M.; Zhao, J.; Li, Z.; Xing, B.; Li, X.; Kong, M.; Li, L.; Zhang, Q.; Liu, Y.; et al. An overview of plant phenolic compounds and their importance in human nutrition and management of type 2 diabetes. Molecules 2016, 21, 1374. [CrossRef]

102. de Araújo, F.F.; de Paulo Farias, D.; Neri-Numa, I.A.; Pastore, G.M. Polyphenols and their applications: An approach in food chemistry and innovation potential. Food Chem. 2021, 338, 127535. [CrossRef]

103. Albuquerque, B.R.; Heleno, S.A.; Oliveira, M.B.P.P.; Barros, L.; Ferreira, I.C.F.R. Phenolic compounds: Current industrial applications, limitations and future challenges. Food Funct. 2021, 12, 14-29. [CrossRef]

104. Pedreiro, S.; da Ressurreição, S.; Lopes, M.; Cruz, M.T.; Batista, T.; Figueirinha, A.; Ramos, F. Crepis vesicaria 1. Subsp. taraxacifolia leaves: Nutritional profile, phenolic composition and biological properties. Int. J. Environ. Res. Public Health 2021, $18,151$. [CrossRef]

105. Liberal, J.; Francisco, V.; Costa, G.; Figueirinha, A.; Amaral, M.T.; Marques, C.; Girão, H.; Lopes, M.C.; Cruz, M.T.; Batista, M.T. Bioactivity of fragaria vesca leaves through inflammation, proteasome and autophagy modulation. J. Ethnopharmacol. 2014, 158, 113-122. [CrossRef]

106. Francisco, V.; Costa, G.; Figueirinha, A.; Marques, C.; Pereira, P.; Miguel Neves, B.; Celeste Lopes, M.; García-Rodríguez, C.; Teresa Cruz, M.; Teresa Batista, M. Anti-inflammatory activity of Cymbopogon citratus leaves infusion via proteasome and nuclear factor-kB pathway inhibition: Contribution of chlorogenic acid. J. Ethnopharmacol. 2013, 148, 126-134. [CrossRef]

107. Borges, P.H.O.; Pedreiro, S.; Baptista, S.J.; Geraldes, C.F.G.C.; Batista, M.T.; Silva, M.M.C.; Figueirinha, A. Inhibition of $\alpha-$ glucosidase by flavonoids of Cymbopogon citratus (DC) Stapf. J. Ethnopharmacol. 2021, 280, 114470. [CrossRef]

108. Amit, S.K.; Uddin, M.M.; Rahman, R.; Islam, S.M.R.; Khan, M.S. A review on mechanisms and commercial aspects of food preservation and processing. Agric. Food Secur. 2017, 6, 51. [CrossRef]

109. Ganiari, S.; Choulitoudi, E.; Oreopoulou, V. Edible and active films and coatings as carriers of natural antioxidants for lipid food. Trends Food Sci. Technol. 2017, 68, 70-82. [CrossRef]

110. Das, A.K.; Rajkumar, V.; Nanda, P.K.; Chauhan, P.; Pradhan, S.R.; Biswas, S. Antioxidant efficacy of litchi (Litchi chinensis Sonn.) Pericarp extract in sheep meat nuggets. Antioxidants 2016, 5, 16. [CrossRef]

111. Sordini, B.; Veneziani, G.; Servili, M.; Esposto, S.; Selvaggini, R.; Lorefice, A.; Taticchi, A. A quanti-qualitative study of a phenolic extract as a natural antioxidant in the frying processes. Food Chem. 2019, 279, 426-434. [CrossRef]

112. Chibane, B.; Bouarab Chibane, L.; Degraeve, P.; Ferhout, H.; Bouajila, J.; Oulahal, N. Open archive toulouse archive ouverte plant antimicrobial polyphenols as potential natural food preservatives. J. Sci. Food Agric. 2018, 99, 1457-1474. [CrossRef]

113. Perron, N.R.; Brumaghim, J.L. A review of the antioxidant mechanisms of polyphenol compounds related to iron binding. Cell Biochem. Biophys. 2009, 53, 75-100. [CrossRef] 
114. Rojas-Bravo, M.; Rojas-Zenteno, E.G.; Hernández-Carranza, P.; Ávila-Sosa, R.; Aguilar-Sánchez, R.; Ruiz-López, I.I.; OchoaVelasco, C.E. A potential application of mango (Mangifera indica L. cv. manila) peel powder to increase the total phenolic compounds and antioxidant capacity of edible films and coatings. Food Bioprocess Technol. 2019, 12, 1584-1592. [CrossRef]

115. Nunes, C.; Maricato, É.; Gonçalves, F.J.; da Silva, J.A.L.; Rocha, S.M.; Coimbra, M.A. Properties of chitosan-genipin films grafted with phenolic compounds from red wine. Trends Carbohydr. Res. 2015, 7, 25-32.

116. Talón, E.; Trifkovic, K.T.; Nedovic, V.A.; Bugarski, B.M.; Vargas, M.; Chiralt, A.; González-Martínez, C. Antioxidant edible films based on chitosan and starch containing polyphenols from thyme extracts. Carbohydr. Polym. 2017, 157, 1153-1161. [CrossRef]

117. Benbettaïeb, N.; Mahfoudh, R.; Moundanga, S.; Brachais, C.H.; Chambin, O.; Debeaufort, F. Modeling of the release kinetics of phenolic acids embedded in gelatin/chitosan bioactive-packaging films: Influence of both water activity and viscosity of the food simulant on the film structure and antioxidant activity. Int. J. Biol. Macromol. 2020, 160, 780-794. [CrossRef]

118. Abdul-Rahman, S.M.; Abass, A.F. Preparation of edible films made from chitosan with pomegranate peel extract and study its barrier, mechanical and antioxidant properties. IOP Conf. Ser. Earth Environ. Sci. 2021, 761, 012122. [CrossRef]

119. Lopes, J.; Gonçalves, I.; Nunes, C.; Teixeira, B.; Mendes, R.; Ferreira, P.; Coimbra, M.A. Potato peel phenolics as additives for developing active starch-based films with potential to pack smoked fish fillets. Food Packag. Shelf Life 2021, 28, 100644. [CrossRef]

120. Kaczmarek-Szczepańska, B.; Wekwejt, M.; Mazur, O.; Zasada, L.; Pałubicka, A.; Olewnik-Kruszkowska, E. The physicochemical and antibacterial properties of chitosan-based materials modified with phenolic acids irradiated by UVC light. Int. J. Mol. Sci. 2021, 22, 6472. [CrossRef]

121. Wang, W.; Zhang, Y.; Yang, Z.; He, Q. Effects of incorporation with clove (Eugenia caryophyllata) essential oil (CEO) on overall performance of chitosan as active coating. Int. J. Biol. Macromol. 2021, 166, 578-586. [CrossRef]

122. da Silva, T.B.V.; Moreira, T.F.M.; Oliveira, A.D.; Bilck, A.P.; Gonçalves, O.H.; Ferreira, I.C.F.R.; Barros, L.; Barreiro, M.-F.; Yamashita, F.; Shirai, M.A.; et al. Araucaria angustifolia (Bertol.) Kuntze extract as a source of phenolic compounds in TPS/PBAT active films. Food Funct. 2019, 10, 7697-7706. [CrossRef]

123. Vieira, M.G.A.; Da Silva, M.A.; Dos Santos, L.O.; Beppu, M.M. Natural-based plasticizers and biopolymer films: A review. Eur. Polym. J. 2011, 47, 254-263. [CrossRef]

124. Falcó, I.; Flores-Meraz, P.L.; Randazzo, W.; Sánchez, G.; López-Rubio, A.; Fabra, M.J. Antiviral activity of alginate-oleic acid based coatings incorporating green tea extract on strawberries and raspberries. Food Hydrocoll. 2019, 87, 611-618. [CrossRef]

125. Bangar, S.P.; Purewal, S.S.; Trif, M.; Maqsood, S.; Kumar, M.; Manjunatha, V.; Rusu, A.V. Functionality and applicability of starch-based films: An eco-friendly approach. Foods 2021, 10, 2181. [CrossRef] [PubMed]

126. Salgado, P.R.; Di Giorgio, L.; Musso, Y.S.; Mauri, A.N. Recent developments in smart food packaging focused on biobased and biodegradable polymers. Front. Sustain. Food Syst. 2021, 5, 125. [CrossRef]

127. Zhu, F. Polysaccharide based films and coatings for food packaging: Effect of added polyphenols. Food Chem. 2021, 359, 129871. [CrossRef] [PubMed]

128. Fernández-Marín, R.; Fernandes, S.C.M.; Sánchez, M.Á.A.; Labidi, J. Halochromic and antioxidant capacity of smart films of chitosan/chitin nanocrystals with curcuma oil and anthocyanins. Food Hydrocoll. 2022, 123, 107119. [CrossRef]

129. Yun, D.; Cai, H.; Liu, Y.; Xiao, L.; Song, J.; Liu, J. Development of active and intelligent films based on cassava starch and Chinese bayberry (Myrica rubra Sieb. et Zucc.) anthocyanins. RSC Adv. 2019, 9, 30905-30916. [CrossRef]

130. Santhosh, R.; Nath, D.; Sarkar, P. Novel food packaging materials including plant-based byproducts: A review. Trends Food Sci. Technol. 2021, 118, 471-489. [CrossRef]

131. Mustafa, P.; Niazi, M.B.K.; Jahan, Z.; Rafiq, S.; Ahmad, T.; Sikander, U.; Javaid, F. Improving functional properties of PVA/starchbased films as active and intelligent food packaging by incorporating propolis and anthocyanin. Polym. Polym. Compos. 2020, 29, 1472-1484. [CrossRef]

132. Zhang, J.; Zou, X.; Zhai, X.; Huang, X.W.; Jiang, C.; Holmes, M. Preparation of an intelligent pH film based on biodegradable polymers and roselle anthocyanins for monitoring pork freshness. Food Chem. 2019, 272, 306-312. [CrossRef]

133. Wang, X.; Yong, H.; Gao, L.; Li, L.; Jin, M.; Liu, J. Preparation and characterization of antioxidant and pH-sensitive films based on chitosan and black soybean seed coat extract. Food Hydrocoll. 2019, 89, 56-66. [CrossRef]

134. Zhang, H.; Jung, J.; Zhao, Y. Preparation, characterization and evaluation of antibacterial activity of catechins and catechins-Zn complex loaded $\beta$-chitosan nanoparticles of different particle sizes. Carbohydr. Polym. 2016, 137, 82-91. [CrossRef]

135. Figueirinha, A.; Cruz, M.T.; Francisco, V.; Lopes, M.C.; Batista, M.T. Anti-inflammatory activity of Cymbopogon citratus leaf infusion in lipopolysaccharide-stimulated dendritic cells: Contribution of the polyphenols. J. Med. Food 2010, 13, 681-690. [CrossRef]

136. Regulation (EC) No 1935/2004 of the European Parliament and of the Council of 27 October 2004 on materials and articles intended to come into contact with food and repealing Directives 80/590/EEC and 89/109/EEC. Off. J. Eur. Union 2004, 4-17.

137. Commission Regulation (EC) No 450/2009 of 29 May 2009 on active and intelligent materials and articles intended to come into contact with food. Off. J. Eur. Union 2009, 3-11.

138. Kocira, A.; Kozłowicz, K.; Panasiewicz, K.; Staniak, M.; Szpunar-Krok, E.; Hortyńska, P. Polysaccharides as edible films and coatings: Characteristics and influence on fruit and vegetable quality-A review. Agronomy 2021, 11, 813. [CrossRef]

139. Regulation (EC) No 1334/2008 of the european parliament and of the council of 16 December 2008 on flavourings and certain food ingredients with flavouring properties for use in and on foods and amending Council Regulation (EEC) No 1601/91, Regulations (EC) No 2232/96 and (EC) No 110/2008 and Directive 2000/13/EC. Off. J. Eur. Union 2008, 34-50. 